\title{
A ditadura nas representaçóes verbais e visuais da grande imprensa: 1964-1969
}

Rodrigo Patto Sá Motta*

\section{RESUMO}

O artigo consiste em estudo das representaçóes divulgadas pela grande imprensa do eixo Rio-São Paulo sobre o regime militar em sua fase inicial, o período entre 1964 e 1969. Para analisar os discursos emitidos pelos seis diários enfocados na pesquisa foram privilegiados os textos dos editoriais e as caricaturas políticas, elementos que se destacam em meio às representaçôes visuais e verbais dos jornais. O propósito é perceber melhor as ambiguidades da imprensa que, cindida entre o amor à liberdade e a devoção à ordem, adotou atitudes tanto de apoio quanto de crítica ao Estado autoritário.

Palavras-chave: ditadura; imprensa; caricatura; representaçôes; política.

\begin{abstract}
The article focuses on Rio and São Paulo media representations concerning the military regime in its initial phase, from 1964 to 1969. The analysis takes into consideration the editorials and the political cartoons published by six daily newspapers examined in the research. This study offers a better understanding of the paradoxical attitudes of the daily press. Split between love for liberty and devotion to social order, the newspapers were both supportive and critical of the dictatorship.
\end{abstract}

Keywords: dictatorship; press; caricature; representations; politics.

* Doutor em história econômica pela Universidade de São Paulo, professor associado da Universidade Federal de Minas Gerais, bolsista de produtividade científica do CNPq, nível 2. Belo Horizonte, MG, Brasil. E-mail: rodrigopsamotta@ gmail.com. 


\section{Introdução}

Este artigo é o primeiro resultado de pesquisa ainda em andamento, que tem como objeto as representaçóes divulgadas pela grande imprensa acerca do regime militar. ${ }^{1}$ Mais precisamente, o olhar se concentra na fase entre abril de 1964 e novembro de 1969, e a escolha do recorte final deve-se à intenção de avaliar o impacto do AI-5 no discurso jornalístico. Para captar e analisar as representaçóes publicadas nos jornais, a opção foi considerar tanto os discursos verbais como os visuais, privilegiando os textos dos editoriais, no primeiro caso, e as caricaturas políticas, no segundo. Analisando ao mesmo tempo essas duas formas de expressão, mas com a devida atenção às especificidades de cada tipo de linguagem, espera-se obter quadro mais amplo das representaçôes jornalísticas sobre o regime militar.

De certo modo, os anos 1960 e 1970 foram o auge da grande imprensa tradicional, se forem consideradas a vendagem e a circulação dos diários. Eram vendidos aproximadamente 5 milhôes de jornais e os diários mais influentes haviam passado por reformas recentes, tornando-se empresas mais sólidas. Também houve diversificação no perfil da imprensa, com a entrada em cena de diários que disputavam o público de mais baixa renda. $\mathrm{O}$ acirramento da competição e as pressóes exercidas pelo regime militar levariam à redução do número de jornais no início dos anos 1970, gerando fenômeno de concentração nas empresas maiores, ao mesmo tempo que as tiragens aumentavam. ${ }^{2}$

Além da competição acirrada e o desafio da modernização, na segunda metade dos anos 1960 a grande imprensa teve de lidar com outro grande dilema, o Estado autoritário. Decerto, toda a grande mídia (salvo Última Hora) apoiou a intervenção militar, contribuindo para configurar o notável apoio civil conferido ao Golpe de 1964. Entretanto, seu apoio não implicava concordância plena com a pauta política da ala extrema-direita do novo regime, que pretendia golpear duramente as instituiçóes liberais em nome da segurança e da ordem (a este respeito, as peculiaridades do Estadão e d'O Globo serão abordadas a seguir). Em sua maioria, os jornais perfilavam com a ala "liberal" dos apoiadores de 1964, que temperavam seu amor pela liberdade com notável transigência a intervençóes autoritárias para defesa do status quo. Por isso, como será mostrado, as relaçôes da imprensa com o regime militar foram marcadas por complexidades e ambiguidades, variando entre o apoio entusiástico e a crítica, situação semelhante, aliás, à que viveram outros setores da sociedade.

Analisar os discursos jornalísticos do período abre novas possibilidades para pensar temas candentes na historiografia. Uma das questôes em discussão hoje é o apoio civil aos militares, e o debate sobre a existência de consenso social em torno do regime autoritário, na contramão dos trabalhos que enfatizam as lutas e estratégias de resistência. ${ }^{3}$ Nessa direção, o estudo da grande imprensa assume importância particular por sua capacidade de influenciar a formação da opinião, ou melhor, das opinióes do público e da sociedade, em uma época em que a televisão ainda estava em consolidação.

Antes de prosseguir é importante apresentar e justificar a escolha do corpus. Os seis periódicos estudados pertencem ao chamado eixo Rio-São Paulo: O Estado de S. Paulo, Folha de S.Paulo, Correio da

\footnotetext{
${ }^{1}$ A pesquisa é financiada pelo CNPq (Bolsa de Produtividade) e pela Fapemig (Programa Pesquisador Mineiro). Agradeço a contribuição dos bolsistas de Iniciação Científica que trabalharam no projeto (Aline Lemos, Izadora Fernando e Getúlio Mendes) e a dos que se engajaram nele recentemente (Thaís Junqueira e Camila Monção).

${ }^{2}$ Sobre tiragens, circulação e reformas na grande imprensa do período, BAHIA, Juarez. Jornal, história e técnica. História da imprensa brasileira. 4. ed. São Paulo: Ática, 1990; BARBOSA, Marialva. História cultural da imprensa no Brasil, $1900-$ 2000. Rio de Janeiro: Mauad X, 2007; ABREU, Alzira A. de. A imprensa em transição: o jornalismo brasileiro nos anos 50. Rio de Janeiro: FGV, 1996; RIBEIRO, Ana Paula Goulart. Modernização e concentração: a imprensa carioca nos anos 19501970. In: NEVES, Lúcia M. B.; MOREL, Marco; FERREIRA, Tania M. B. (Org.). História e imprensa: representaçóes culturais e práticas de poder. Rio de Janeiro: Faperj; DP\&A, 2006. p. 426-435.

${ }^{3}$ REIS FILHO, Daniel Aarão. Ditadura militar, esquerdas e sociedade. 2. ed. Rio de Janeiro: Jorge Zahar, 2002, e também os trabalhos reunidos na coletânea organizada por Denise Rolemberg e Samantha Quadrat: A construçáo social dos regimes autoritários: legitimidade, consenso e consentimento no século XX. Rio de Janeiro: Civilização Brasileira, 2010.
} 
Manhã, Jornal do Brasil, O Globo e Última Hora. Eles foram escolhidos por sua capacidade de circulação e influência, inclusive entre grupos sociais, além das cidades em que eram produzidos. Embora seja problemático pretender fazer história de âmbito nacional com dados apenas das duas capitais, por outro lado, em vista de sua ampla circulação, esses veículos são representativos do discurso jornalístico que chegava a parcelas influentes da sociedade brasileira. A tiragem média de cada um desses diários variava entre 100 e 250 mil exemplares (cerca de 1 milhão na soma dos seis), o que significava aproximadamente $20 \%$ dos jornais produzidos em todo o país. É relevante ressaltar, também, que cada exemplar era lido por quatro pessoas, ${ }^{4}$ portanto, a circulação era bem superior à tiragem. Trata-se de boa amostra da grande imprensa da época, com a presença tanto de jornais que cooperaram com a ditadura, quanto de veículos que entraram em choque com o poder autoritário.

\section{Algumas consideraçôes teóricas e comentários sobre a bibliografia}

A imprensa começou a ser pesquisada há décadas, mas, de maneira semelhante a outros campos, os trabalhos de investigação se adensaram em período recente, a partir do amadurecimento das universidades e dos cursos de pós-graduação. Os trabalhos pioneiros foram escritos por Nelson Werneck Sodré e pelo jornalista Juarez Bahia, no fim dos anos 1960.5 Desde entâo, muitas pesquisas foram realizadas, a maioria tendendo a enfocar um só jornal ou a imprensa de uma das grandes capitais. No caso dos diários paulistas, há que mencionar os estudos pioneiros de Maria Helena Capelato e Maria Lígia Prado e, também, trabalhos mais recentes, como os de Maria Aparecida Aquino e Beatriz Kushnir. ${ }^{6}$ Para a imprensa carioca podem ser citadas, além dos trabalhos de Alzira Alves de Abreu e seus parceiros, as pesquisas de investigadores da área de comunicação, entre eles Marialva Barbosa e Ana Paula Ribeiro Goulart. ${ }^{7}$

Observando esses trabalhos percebe-se que há ainda poucas pesquisas sobre a grande imprensa durante o regime militar. Além disso, estudos dedicados aos grandes diários são menos numerosos do que as pesquisas sobre a imprensa alternativa, talvez mais atraente pelo charme de força de resistência à ditadura. ${ }^{8}$ Chama a atenção, também, a virtual inexistência de trabalhos que tentem dar conta, simultaneamente, do quadro carioca e paulista.

Quanto às caricaturas, as publicações se dividem entre obras de orientação catalográfica/memorialística e trabalhos acadêmicos, os últimos provavelmente em menor número. Estudos pioneiros aparece-

\footnotetext{
${ }^{4}$ BAHIA, Juarez. Jornal, história e técnica, op. cit. p. 372.

${ }^{5}$ No entanto, ambos abordaram a fase da ditadura superficialmente, já que foram escritos em fins dos anos 1960. SODRÉ, Nelson Werneck. História da imprensa no Brasil. Rio de Janeiro: Civilização Brasileira, 1966 e BAHIA, Juarez. Jornal, história e técnica, op. cit.

${ }^{6}$ Eis as referências completas: CAPELATO, Maria Helena. Os arautos do liberalismo: 1920-45. São Paulo: Brasiliense, 1989; CAPELATO, Maria Helena; PRADO, Maria Lígia. O bravo matutino: imprensa e ideologia no jornal O Estado de S. Paulo. São Paulo: Alfa-Ômega, 1980; MOTA, Carlos Guilherme; CAPELATO, Maria Helena. História da Folha de S.Paulo (19211981). São Paulo, 1980; KUSHNIR, Beatriz. Cães de guarda. Jornalistas e censores, do AI-5 à Constituição de 1988. São Paulo: Boitempo, 2004; AQUINO, Maria Aparecida. Censura, imprensa, Estado autoritário (1968-1978): o exercício cotidiano da dominação e da resistência: O Estado de S. Paulo e Movimento. Bauru: Edusc, 1999. Aquino foi uma das poucas autoras a analisar mais de um periódico.

${ }^{7}$ ABREU, Alzira Alves de; LATTMAN-WELTMAN, Fernando; KORNIS, Monica. Midia e politica no Brasil: jornalismo e ficção. Rio de Janeiro: FGV, 2003; ABREU, Alzira A. de. A imprensa em transição, op. cit.; BARBOSA, Marialva. História cultural da imprensa no Brasil, 1900-2000, op. cit.; RIBEIRO, Ana Paula Goulart. Modernização e concentração, op. cit.

${ }^{8}$ Não se questiona a importância das pesquisas sobre a imprensa alternativa, e neste campo há trabalhos muito bons, listados a seguir. No entanto, a grande imprensa deveria receber igual ou maior atenção, devido ao fato de atingir público maior. BRAGA, José Luiz. O Pasquim e os anos 70: mais pra epa que pra oba... Brasília: Ed. UnB, 1991; CHINEM, Rivaldo. Imprensa alternativa: jornalismo de oposição e inovação. São Paulo: Ática, 1995; KUCINSKI, Bernardo. Jornalistas e revolucionários, nos tempos da imprensa alternativa. 2 ed. São Paulo: Edusp, 2003.
} 
ram nos anos 1980, como os trabalhos de Marcos Silva e Isabel Lustosa, a que se seguiram mais alguns autores, sem configurar ainda, ao meu juízo, um campo sólido. Falta maior acúmulo de trabalhos e o aprofundamento nas reflexóes sobre as metodologias de pesquisa, investimentos que valem a pena em vista da importância da linguagem caricatural nos embates políticos. As pesquisas sobre caricaturas expressão que engloba tanto as caricaturas propriamente ditas como também as charges e os cartuns revelam quadro semelhante ao notado para a imprensa diária: há mais estudos sobre as publicaçóes dos periódicos alternativos, com destaque para O Pasquim e a obra de Henfil, e muito pouco sobre os desenhos publicados nos veículos tradicionais. De forma semelhante, também, os pesquisadores dividem-se entre a historiografia e a área de comunicação. ${ }^{9}$

Reiterando, nesta apresentação serão analisadas as representaçôes verbais e visuais da grande imprensa, mais precisamente, os editoriais e as caricaturas/charges, com atenção às peculiaridades e às convergências entre as duas formas de discurso. Os jornais são encarados, ao mesmo tempo, como fonte e objeto. Trata-se de compreender sua atitude diante do regime militar, levando em conta o papel da imprensa na divulgação de informaçôes, ideias e valores, com potencial para construir consensos, mas, também, para mobilizar a oposição.

As reflexôes de Jürgen Habermas sobre o papel da imprensa na constituição de uma esfera pública tornaram-se clássicas, contribuindo para destacar a relevância política dos jornais e a necessidade de estudá-los. No entanto, nesta direção, muitos trabalhos seguiram caminhos simplistas, reduzindo os periódicos ao papel de mero instrumento nas estratégias discursivas burguesas ou estatais. ${ }^{10}$ Avaliação adequada das fontes de inspiração política da grande imprensa demanda olhar mais cuidadoso. Naturalmente, trata-se de empresas inseridas no sistema capitalista, portanto, contrárias a mudanças sociais radicais. Além disso, os jornais sofrem influência do Estado, seja de ordem financeira, na forma de vantagens ou publicidade oficial, seja pela ameaça de açôes coercitivas. Não obstante, a trajetória política dos jornais revela posicionamentos com distinçóes marcantes, como se verá a seguir. A razão é que a imprensa também sofre a influência do público, da sua clientela; por isso, estratégias de mercado, em certas situaçóes, marcam as escolhas políticas dos editores. Por outro lado, é fundamental considerar a opinião política dos proprietários da empresa ou de seus editores que, às vezes, adotaram estratégias arriscadas motivados por suas convicçôes.

Para avaliar a força da imprensa há que se levar em conta também a resposta do público, que não deve ser considerado uma massa amorfa. É preciso cautela ao avaliar os efeitos reais dos periódicos, assim como de qualquer outra forma de impresso. O simples fato de determinado impresso circular e ser lido não implica recepção unívoca: pode haver apropriaçóes diferentes e usos diversos do pretendido pelos editores, de modo que análises ingênuas devem ser evitadas. Por limitaçôes de espaço não será possível fazer estudo de recepção/apropriação, embora existam possibilidades interessantes a explorar. ${ }^{11}$ De qualquer modo, é evidente que os jornais exerciam impacto significativo, pelo menos assim acreditou o regime militar ao se ocupar de censurá-los e prender jornalistas e chargistas. ${ }^{12}$ Nessa linha de

${ }_{9}^{9}$ SILVA, Marcos. Caricata República. São Paulo: Marco Zero, 1990; LUSTOSA, Isabel. Histórias de presidentes: a República no Catete. Petrópolis: Vozes, 1989. Em anos recentes, alguns historiadores produziram teses sobre o tema, como Elio Flores (República às avessas: narradores do cômico, cultura política e coisa pública no Brasil contemporâneo) e Maria Francisca Pires (Cultura e politica: entre Fradins, Zeferinos, Graúnas e Orelanas).

${ }^{10}$ HABERMAS, Jürgen. Mudança estrutural da esfera pública. Rio de Janeiro: Tempo Brasileiro, 1984.

${ }^{11}$ No caso das caricaturas, sua influência efetiva sobre o debate político se verifica nos casos de figuras inventadas para atacar, respectivamente, Carlos Lacerda e a direita militar: o "corvo" e o "gorila". Essas duas construções caricaturais produziram resultados profundos e duradouros, ao ponto de os grupos atingidos pela zombaria terem se mobilizado para dar resposta aos atacantes, principalmente por meio da estratégia de se apropriar daquelas representaçóes para alterar seu conteúdo crítico. MOTTA, Rodrigo Patto Sá. Jango e o golpe de 1964 na caricatura. Rio de Janeiro: Jorge Zahar, 2006.

${ }^{12}$ O caso mais célebre ocorreu em 1970, quando uma edição d'O Pasquim estampou, na capa, charge que fazia troça de D. Pedro I e do 7 de Setembro. A edição foi recolhida e os jornalistas permaneceram na cadeia por alguns dias. Em 1964, 
raciocínio, outra consideração importante diz respeito ao perfil social do público leitor. As pessoas que liam esses diários pertenciam, na maioria, a grupos privilegiados na escala social. ${ }^{13}$ Essa constatação não reduz a relevância do objeto: dado o caráter elitista da vida política brasileira, as opinióes e o "estado de espírito" das classes média e alta têm grande relevância, tanto no apoio como na oposição ao governo.

O estudo das caricaturas mobiliza problemas teóricos e metodológicos específicos, que demandam atenção. Um dos desafios teóricos no estudo de imagens é saber se a representação visual corresponde à verdade, ou à realidade. Isso pode parecer deslocado no caso das caricaturas, que são, declaradamente, distorçôes e deformaçôes, raiando ao grotesco. Mas as coisas não são assim tão simples. Embora carregando, zombando ou fazendo galhofa, a caricatura almeja trazer à tona a verdade, ao menos facetas dela.

A inspiração teórica para lidar com as imagens visuais apoia-se, seletivamente, nas reflexôes da iconologia e da semiologia, embora elas tenham estudado imagens de outra natureza, salvo um penetrante ensaio de Ernst Gombrich sobre o "arsenal do cartunista". ${ }^{14} \mathrm{Da}$ iconologia, reteve-se a ênfase em interpretar o sentido das imagens, tratando-as como fontes de informação a serem submetidas à crítica. ${ }^{15}$ Da semiologia são inspiradoras as reflexôes sobre os laços entre linguagem verbal e visual, que usam recursos semelhantes, como metáfora, metonímia e ironia. É importante estar atento à combinação entre imagem e texto, este exercendo a função de ancoragem ao dirigir o olhar no sentido da compreensão desejada pelo autor do desenho. ${ }^{16}$

No entanto, em certos casos a leitura das caricaturas dispensa grandes acrobacias interpretativas, já que se trata de linguagem visual com vocação para atingir o grande público. O caricaturista deseja ser compreendido pela maioria, às vezes até mesmo os analfabetos, por isso, salvo situaçôes especiais, raramente os desenhos são herméticos. Muitas vezes, o principal trabalho é reconstruir os contextos e identificar personagens, com atenção, também, às convençôes desta arte que depende da criatividade e do gênio individual, mas, igualmente, é caudatária de códigos de linguagem construídos ao longo de quatro séculos.

Praticada pelo menos desde o século XVII, ${ }^{17}$ a caricatura foi incorporada à imprensa no século XIX. Os grafismos cômicos atuam no comentário dos acontecimentos e atos dos líderes políticos, quase como crônicas visuais, auxiliando os jornais em seu papel de produzir notícias e influenciar a opinião política. Frequentemente, as imagens expressam, mais que opiniôes pessoais, o ponto de vista do jornal, às vezes reduzindo-se à charge editorial, cujo papel é ilustrar e fixar o pensamento da empresa. Ainda assim, alguma autonomia para o desenhista existia em certos casos, embora situaçóes de desencontro frontal com a linha editorial não durassem muito, como se verá no caso de Claudius e o Jornal do Brasil.

Nos jornais em foco atuaram vários artistas de grande talento. Além de Claudius destacaram-se, também, Henfil, Ziraldo, Fortuna, Augusto Bandeira, Lan, Jaguar, Orlando Mattos, Hilde, entre outros. Com criatividade e humor, eles marcaram o modo como o público dos jornais imaginou e compreendeu as disputas políticas do contexto. O traço conciso e a utilização de recursos usuais do humor (contraste,

o chargista Claudius também foi detido, em represália a suas críticas contra os militares.

${ }_{13}^{13}$ BAHIA, Juarez. Jornal, história e técnica, op. cit. p. 372-373. Deve-se abrir exceçấo para o caso de Última Hora, que tinha grande penetração popular, embora fosse lido por segmentos de elite também.

${ }^{14}$ GOMBRICH, Ernst. O arsenal do cartunista. In: GOMBRICH, Ernst. Meditaçôes sobre um cavalinho de pau e outros ensaios sobre teoria da arte. São Paulo: Edusp, 1999. A filiação de Gombrich à escola da iconologia pode ser questionada, mas, de qualquer forma, ele pertencia ao Instituto Warburg, local onde ela se originou.

${ }^{15}$ PANOFSKY, Erwin. Estudos de iconologia. Lisboa: Estampa, 1986. Além de Panofsky, outros nomes do Instituto Warburg são referências importantes para estas reflexóes, como Ernst Gombrich e Michael Baxandall. Para um balanço sobre os méritos e limites da iconologia e da semiologia, ver: BURKE, Peter. Testemunha ocular. História e imagem. Bauru, SP: Edusc, 2004. p. 213-223.

${ }^{16} \mathrm{O}$ conceito de ancoragem foi desenvolvido por BARTHES, Roland. Rhétorique de l'image. In: BARTHES, Roland. Oeuvres complètes. Tome II. Paris: Éditions du Seuil, 2002. p. 573-588.

${ }^{17}$ LIMA, Herman. História da caricatura no Brasil. Rio de Janeiro: José Olympio, 1963. p. 6-9. 
surpresa, rebaixamento, deformação) tornam a caricatura propícia para a crítica política em períodos autoritários. Como o sentido da mensagem é dúbio, ambíguo, maiores as chances de burlar a repressão e a censura. Por isso, sobretudo depois do AI-5, as caricaturas serviram de meio para manifestar críticas sutis ao Estado, expressando argumentos que não poderiam ser apresentados por meio dos textos verbais.

\section{A grande imprensa no período 1964-1969: entre a liberdade e a ordem}

$\mathrm{Na}$ pesquisa que originou este texto foram coletados milhares de caricaturas e editoriais. Evidentemente, é impossível usar todo esse material no espaço de um artigo, daí a necessidade de selecionar com cuidado e sintetizar. Infelizmente, e pela mesma razão, tampouco será possível analisar com o devido detalhe todas as charges citadas. Outra opção seria reduzir o número de imagens para poder analisá-las minuciosamente, mas, neste caso, se perderia a oportunidade de oferecer um quadro mais abrangente.

De início, é importante considerar os dilemas da grande imprensa diante do regime autoritário, cindida entre a devoção à liberdade e o amor à ordem, oscilante entre o desejo de autonomia e a dependência e os favores do Estado. Por convicção e por interesse, as empresas jornalísticas são favoráveis à liberdade de manifestação, notadamente quando as restrições atingem-nas também. Por isso, quando o regime militar adotou medidas para cercear a imprensa e agrediu os valores liberais tradicionais (opinião, manifestação, garantias individuais), a maioria dos veículos jornalísticos mostrou-se descontente.

Exceto $O$ Globo, todos os jornais analisados criticaram a censura e a intensificação da legislação autoritária, e todos se apresentaram como adeptos dos valores liberais e democráticos, inclusive $O$ Globo. Porém, a intensidade das críticas variou bastante, assim como a disposição para correr riscos. Para facilitar a análise, pode-se dividi-los em dois blocos, agrupados de acordo com as atitudes adotadas diante da ditadura: O Estado de S. Paulo (OESP), Jornal do Brasil (JB), Folha de S.Paulo (FSP) e O Globo, de um lado, e Correio da Manhã (CM) e Última Hora (UH), na outra ponta.

OESP, FSP, O Globo e JB apoiaram a "revolução" decididamente, por sua repulsa aos rumos que parecia tomar o governo Goulart. A adoção da expressão "revolução" (e eles não usavam aspas) revela o modo positivo como encararam o novo regime, que utilizava esse termo para obter legitimidade. Como os outros setores liberais e conservadores da sociedade brasileira, a grande imprensa preferiu os riscos da intervenção militar às ameaças de um processo de esquerdização com apoio no Estado, tendência que identificaram no governo deposto. Nos primeiros anos, pelo menos até o AI-5, esses diários reivindicaram a "revoluçáa" como obra sua também, e reclamaram o direito de influenciar seus rumos. Eles aferraram-se ao argumento de que os "ideais" de 1964 estavam ancorados na defesa da liberdade, supostamente ameaçada por Goulart e aliados, e quando os novos governantes passaram a agredir a sua concepção de liberdade reclamaram o retorno aos princípios de "31 de março", como se todos os atores de 1964 se identificassem com os mesmos valores. Era posição ambígua, um liberalismo pronto a fazer concessôes ao autoritarismo. Entretanto, isso não significa que a ligação com os valores liberais fosse irrelevante ou apenas retórica, pois, como será mostrado, no momento da crise de 1968 quase todos divergiram da solução ditatorial.

Nas primeiras semanas após a intervenção militar de 1964, os quatro diários do primeiro bloco (OESP, FSP, JB e $O$ Globo) apoiaram as medidas repressivas, que acharam necessárias para consolidar a nova ordem. Porém aí já começaram a aparecer nuanças a diferenciá-los, pois o entusiasmo com a “operação limpeza" variou a depender do veículo, de modo que o melhor é analisá-los separadamente.

Entre os quatro, o menos entusiástico na adesão aos expurgos foi o JB, que temperou seu apoio com pedidos de moderação e respeito às leis, para não ferir as instituiçóes em vigor e evitar injustiças. Em editorial de 6 de maio de 1964, por exemplo, o JB fez declaração de engajamento na "revolução" e, com 
base nessa filiação, pediu ao governo que limitasse o escopo dos expurgos, para diminuir a intranquilidade e náo propiciar aos adversários do novo regime um argumento crítico eficaz. Apesar de tais nuanças, o JB era simpático ao novo regime, o que causou dificuldades para um de seus chargistas, Claudius, cuja opinião era diferente. Os desenhos de Claudius imediatamente após o Golpe mostram desconforto com o novo poder, como a ironia sobre o Castelo dominando o Palácio da Alvorada (figura 1: a metáfora do castelo representava tanto o presidente Castelo Branco como o poder militar), ou a denúncia jocosa das arbitrariedades do expurgo anticomunista (figura 2). Suas charges implicavam dissonância com a linha editorial e, por isso, suas publicaçóes no JB foram escassas nos meses seguintes. Neste caso, houve desencontro entre a disposição crítica do chargista e a moderação do jornal e, provavelmente por essa razão, em 1966 ele saiu do JB. Pouco depois, Claudius foi contratado por UH e CM, jornais mais de acordo com seu perfil, e ali publicou ataques bastante agressivos ao regime e ao seu aparato repressivo nos anos de 1967 e 1968.
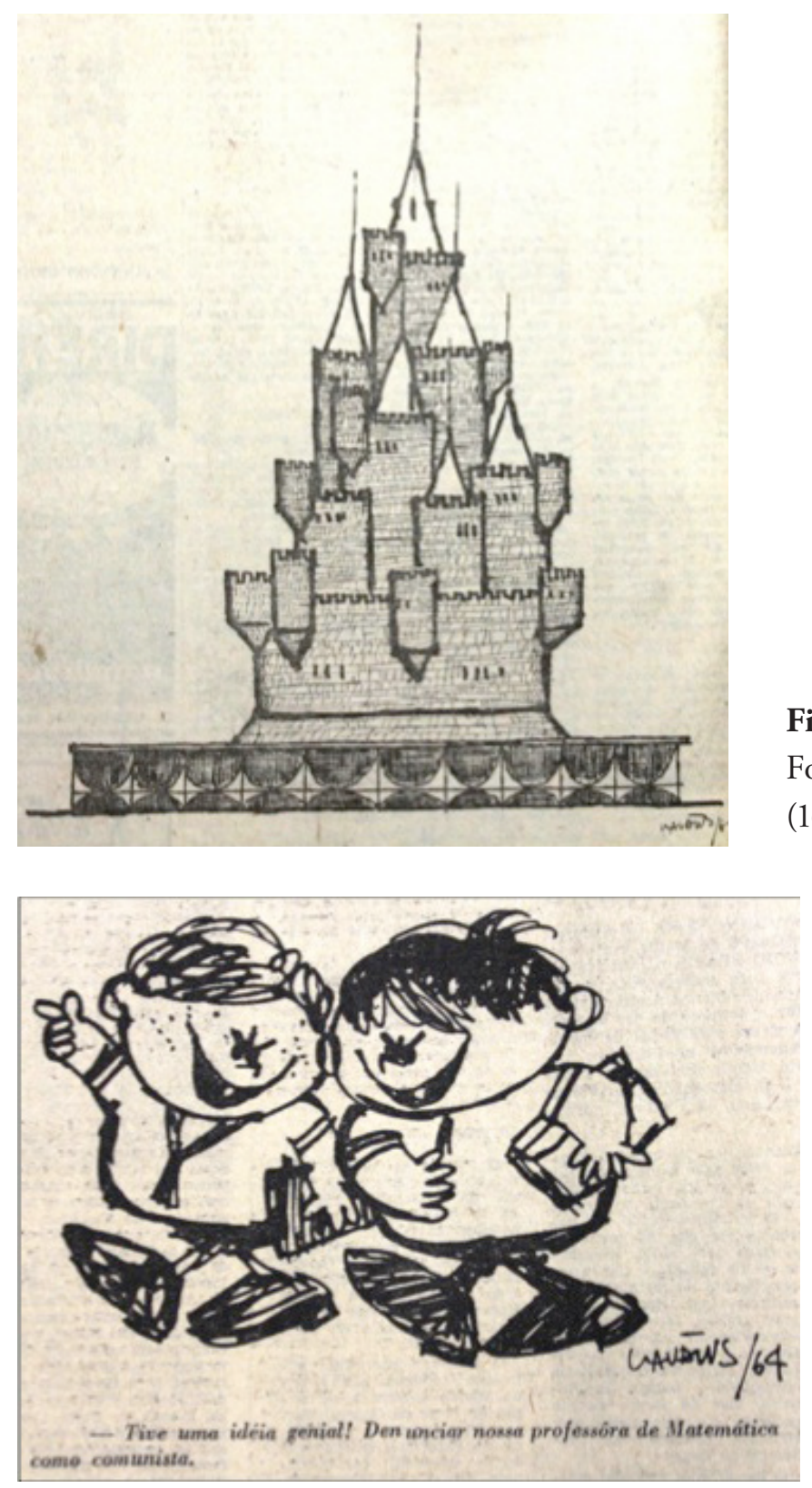

Figura 1: Claudius Fonte: Jornal do Brasil (16 abr. 1964).
Figura 2: Claudius Fonte: Jornal do Brasil (7 abr. 1964). 
No caso da FSP houve entusiasmo ainda maior com a nova situaçáo política, principalmente o governo Castelo Branco, que o periódico recebeu com esperança e otimismo. Os caricaturistas da Folha, Orlando Mattos e Nelson Coletti, deram expressão visual às opiniôes do jornal em numerosas charges editoriais. Nos primeiros meses do governo Castelo Branco saíram muitas caricaturas simpáticas (e, naturalmente, insossas) ao general presidente na FSP, retratado como dirigente comprometido com a reconstrução do Brasil e fiel a valores liberais. Nessa linha, eles tentaram afastar o presidente da ala radical do regime que desejava intensificar as medidas autoritárias. Para fixar esse ponto, os chargistas da FSP criaram uma figura caricatural, a senhora "falsa democracia", que pressionava Castelo Branco para o fechamento do regime, principalmente o cancelamento de eleiçóes (figura 3). O jornal defendia a importância das eleiçôes e da "liberdade" e apostava — fazendo pressão também — que Castelo seria capaz de evitar o recrudescimento autoritário, como nas caricaturas em que aparece confirmando a realização de eleiçóes e segurando a "linha-dura" pelo rabo (figuras 4 e 5). Os ataques à "falsa democracia”, veladamente, implicavam críticas ao jornal dominante em São Paulo, o Estadão, que demandava o adiamento das eleiçôes de 1965.

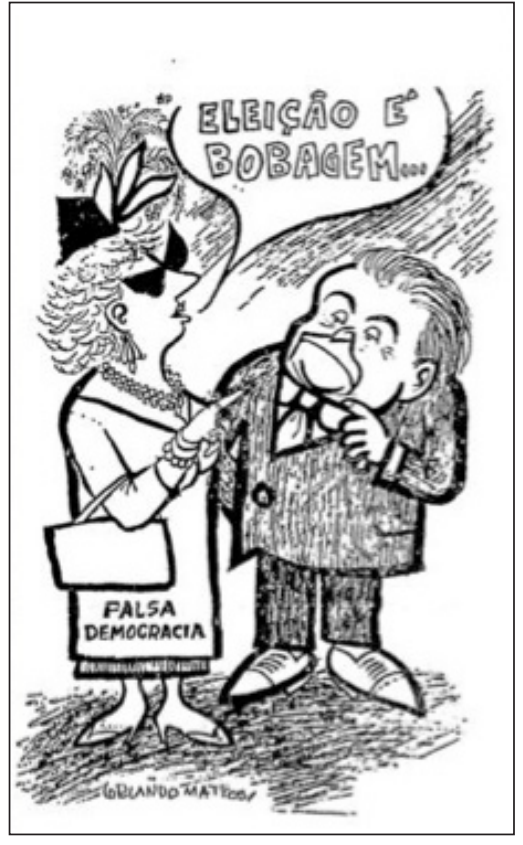

Figura 3: Orlando Mattos

Fonte: Folha de S.Paulo

(4 fev. 1965).

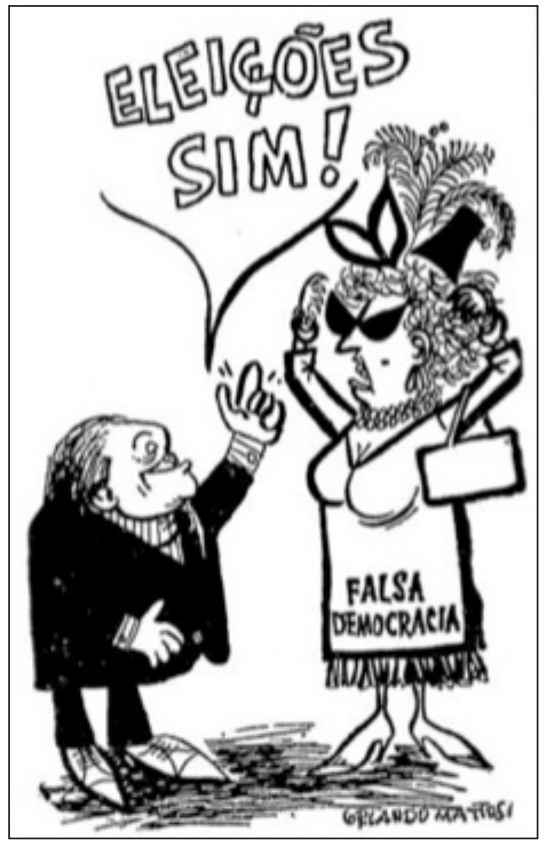

Figura 4: Orlando Mattos

Fonte: Folha de S.Paulo

(13 fev. 1965).

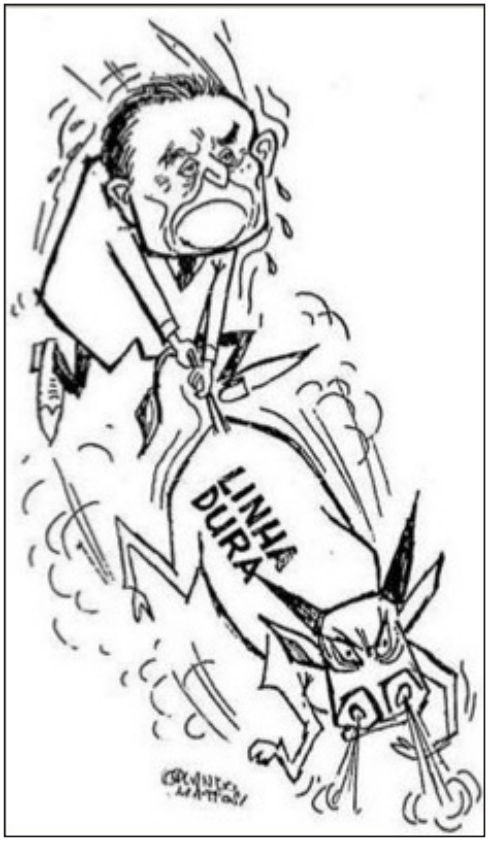

Figura 4: Orlando Mattos

Fonte: Folha de S.Paulo

(16 set. 1964).

Entre os que apoiaram a intervenção militar, o mais engajado foi sem dúvida o Estadão, cujo proprietário, Júlio de Mesquita Filho, nos editoriais do diário, descreveu-se como "revolucionário" e conspirador de primeira hora. Conduzido por "Julinho" Mesquita, OESP esteve a serviço de sua visão sobre o significado do "31 de março", cuja verdadeira essência ele pretendia encarnar. Neste caso, temos exemplo extremo das ambiguidades dos "liberais democratas" que apoiaram a repressão política. Mas, aos olhos dos editores de OESP, não havia qualquer dubiedade: seguindo linha de pensamento apresentada por Carlos Lacerda nos anos 1950, o jornal dos Mesquita defendia que a "revoluçáo" deveria durar de dois a três anos, seguindo o modelo das ditaduras da República Romana. Após essa intervenção, rápida e intensa, que deveria erradicar os males do país, a saber, o getulismo, o comunismo e a corrupção, o poder deveria ser devolvido aos civis, com pleno restabelecimento das instituiçóes liberais democráticas. 
Como desejasse incursão ditatorial breve, o OESP não concordava com alteraçóes na Constituição, nem com o estabelecimento de mecanismos autoritários duradouros.

O Estadão foi um dos primeiros jornais da grande imprensa "revolucionária" a criticar Castelo Branco. O tradicional diário considerou o presidente excessivamente moderado nos expurgos e equivocadamente inclinado à acomodaçáo com lideranças do regime anterior. Não agradou ao jornal o fato de Castelo Branco apresentar medidas reformistas ao Congresso, como projetos de reforma agrária e de estabelecimento de voto para os analfabetos, iniciativas semelhantes às defendidas por Goulart. ${ }^{18}$ Entre abril de 1964 e o final de 1965, o OESP foi uma espécie de porta-voz da linha-dura. Além de exigir maior dureza contra os "comunistas e subversivos", OESP contribuiu para a construçáo de outro inimigo do novo regime, a corrupção. O tema fazia parte do imaginário liberal desde os anos 1950, mas, nas representaçôes veiculadas contra o governo Goulart, a corrupção foi tema secundário diante da proeminência do argumento anticomunista. ${ }^{19}$ Com o advento do novo regime começou a construçáo do tema dos dois inimigos da "revolução", o par subversão e corrupção, com contribuição destacada do Estadão. ${ }^{20}$

As charges de Hilde e Biganti acompanharam com fidelidade a linha editorial de OESP. Por vezes, eles se limitaram a ilustrar os textos, mas, em outros casos, foram mais criativos, elaborando artifícios visuais que ofereciam novas possibilidades para representar as posiçôes do jornal. $\mathrm{Na}$ fase inicial, em que prevalecia a simpatia por Castelo Branco, Biganti adotou a metáfora do Castelo em sentido positivo, como símbolo da mudança de 1964. A fortaleza representava a solidez do novo poder e sua capacidade de preservar a ordem (figura 6). Os chargistas do Estadão apoiaram os expurgos e as cassaçóes com entusiasmo ímpar, como se pode ver nas figuras 7 e 8. Dedetizadores (a empresa se chama "31 de março") e navios (notem-se os símbolos nas bandeiras: a foice e martelo no barco afundado, a bandeira pirata no que estava sob ataque) serviram como metáforas para evocar a "operação limpeza" das instituições, assim como para mencionar o ataque ao comunismo e à corrupção. Essas charges ajudaram a construir as representaçôes visuais dos inimigos a combater, agregando um tema novo, as ratazanas, bichos repelentes mobilizados para aludir à "sujeira" que se pretendia limpar (figura 9). No caso da figura 9, importante notar a representação da "Revolução" como uma senhora com ares de dona de casa, soluçáo visual muito utilizada nas charges que tem relação com o gênero feminino da palavra revolução, mas também significa menção ao apoio de grupos femininos de direita ao Golpe. Na imagem, a senhora usara o porrete para abater a "serpente" comunista e se preparava para pegar outro bicho repelente, um rato, que representa a corrupção. Esta interpretaçáo se sustenta na leitura de editorial anterior, que havia mencionado o combate à corrupção como o "segundo objetivo" do novo poder e, também, porque o rato configura metáfora tradicional para a idéia de sujeira e corrupção. Até o final da vigência do primeiro Ato Institucional, os chargistas do Estadão continuaram apoiando as medidas repressivas, como a proibição da UNE e a demissão de funcionários públicos, aí incluído o grupo de professores de medicina da USP expurgado em outubro de 1964 (figuras 10 e 11). ${ }^{21}$

\footnotetext{
${ }^{18}$ Ver editoriais das seguintes ediçóes: 11/4, 14/4 e 14/5/1964.

${ }^{19}$ MOTTA, Rodrigo Patto Sá. Jango e o golpe de 1964 na caricatura, op. cit.

${ }^{20}$ Editorial de 21/4/1964, "Os postulados da Revolução".

${ }^{21}$ A interpretaçáo de que os pinos de boliche derrubados na figura 11 representam os professores e cientistas aposentados na USP e no Instituto Butantã deve-se à data, à menção ao art. 7o do Ato Institucional (na bola), e também ao uso de convenções gráficas para representar homens do saber (os óculos, as barbas). Note-se que havia também alguns ratos negros entre os pinos derrubados, provavelmente para sugerir a presença de corruptos entre os expurgados.
} 


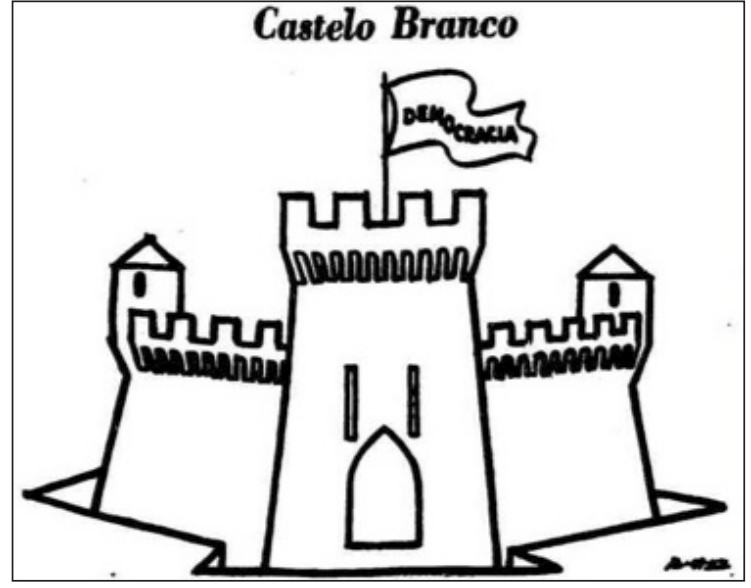

Figura 6: Biganti

Fonte: O Estado de S. Paulo (8 abr. 1964).

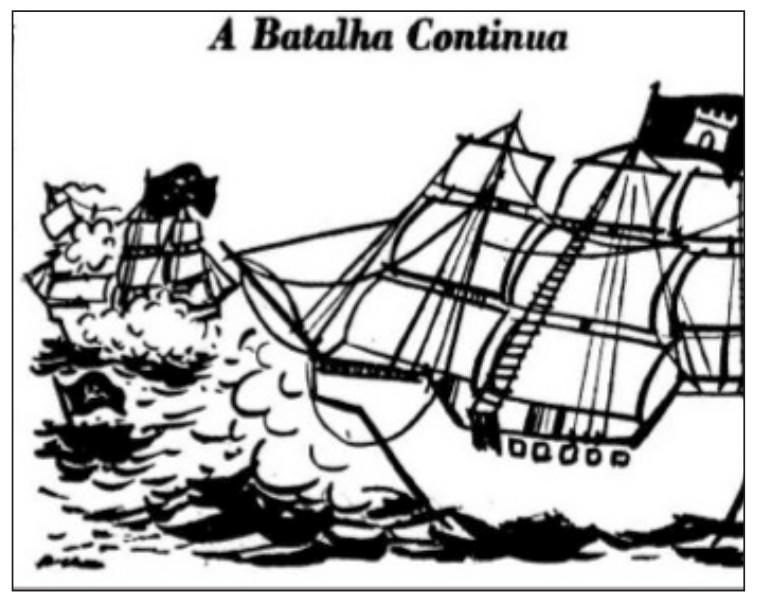

Figura 8: Biganti

Fonte: O Estado de S. Paulo (26 abr. 1964).

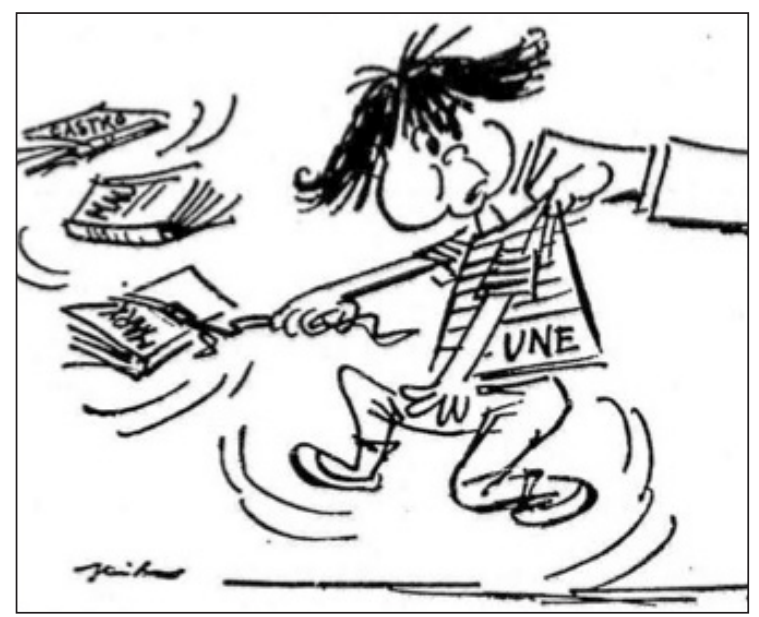

Figura 10: Hilde

Fonte: O Estado de S. Paulo (16 jun. 1964).

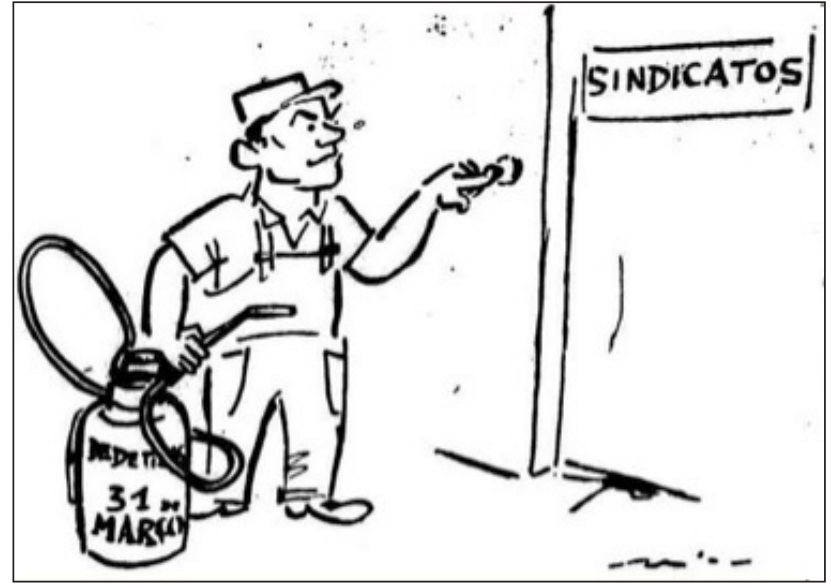

Figura 7: Hilde

Fonte: O Estado de S. Paulo (21 abr. 1964).

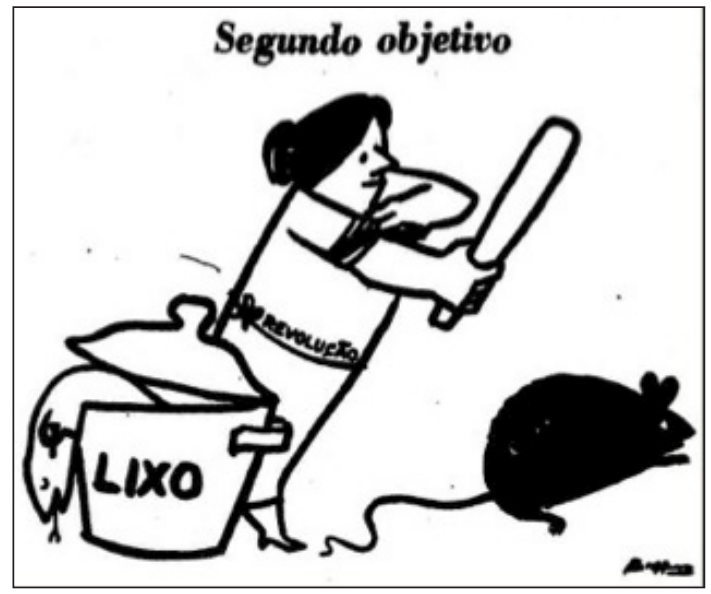

Figura 9: Biganti

Fonte: O Estado de S. Paulo (14 abr. 1964).

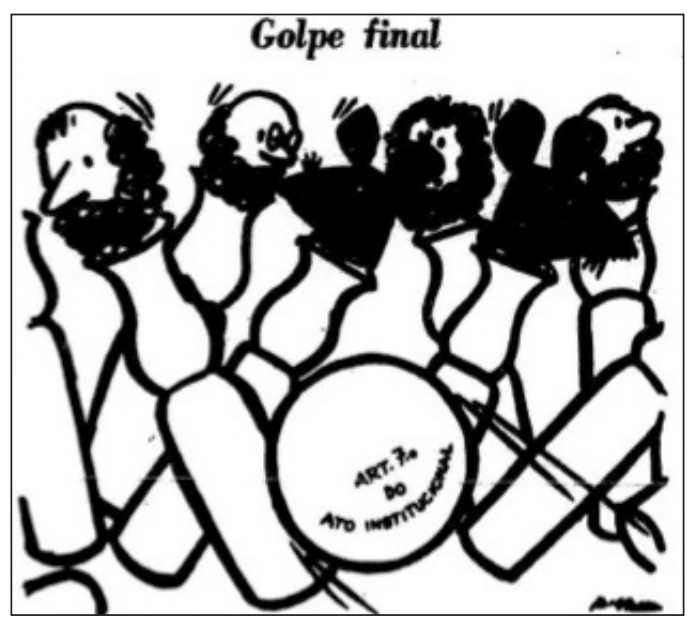

Figura 11: Biganti

Fonte: O Estado de S. Paulo (10 out. 1964). 
Quanto às críticas do Estadão a Castelo Branco, as caricaturas atacaram sua suposta aproximação com os derrotados em 1964. Em um desses desenhos, Hilde representou o fantasma de Jango conduzindo Castelo Branco a assinar o projeto do voto dos analfabetos (figura 12), iniciativa que acabaria depois derrotada pelo Congresso. Inúmeras caricaturas de OESP abordaram temas assemelhados, apontando suposta traição ao que o Estadão considerava os "ideais de março". No final de 1965, no quadro das eleiçóes estaduais e da edição do AI-2, OESP afastou-se ainda mais de Castelo Branco. Julinho de Mesquita defendeu o adiamento das eleiçóes e, com o resultado desfavorável no Rio e em Minas Gerais, em que venceram candidatos da aliança PSD-PTB, ele se alinhou à tese de que os eleitos não poderiam ser empossados para impedir o retorno dos derrotados em 1964. Júlio de Mesquita Filho também discordou do AI-2, que criou eleiçôes indiretas e extinguiu o antigo sistema partidário, medidas que não interessavam à candidatura de Carlos Lacerda, menina dos olhos do Estadão.

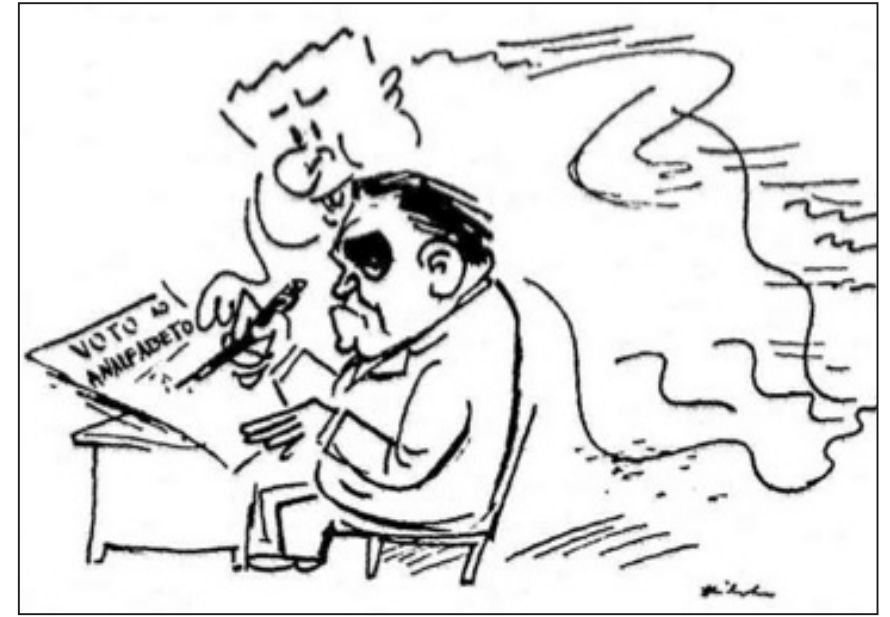

Figura 12: Hilde

Fonte: $O$ Estado de S. Paulo (24 jun. 1964).

No caso da FSP, ao longo de 1965 ela também perdeu entusiasmo com Castelo Branco, mas por motivos diferentes do Estadão. $\mathrm{O}$ motivo do seu incômodo era o aumento progressivo das açóes autoritárias do governo, sobretudo no que toca à liberdade de imprensa e de expressão. No editorial de 29 de maio de 1965, por exemplo, a FSP denunciou a censura às editoras e o texto foi acompanhado de charge aludindo à queima de livros, imagem tradicional para evocar a intolerância às ideias (figura 13). Na mesma linha, foram publicados editoriais e charges contra a censura aos jornais, notadamente criticando o governo pela iniciativa de editar a Lei de Imprensa, no início de 1967, considerada uma agressão à liberdade (figura 14).

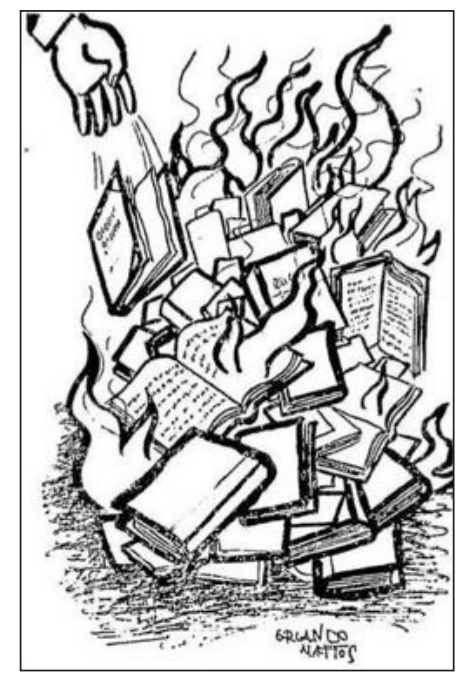

Figura 13: Orlando Mattos

Fonte: Folha de S.Paulo

(29 maio 1965). 


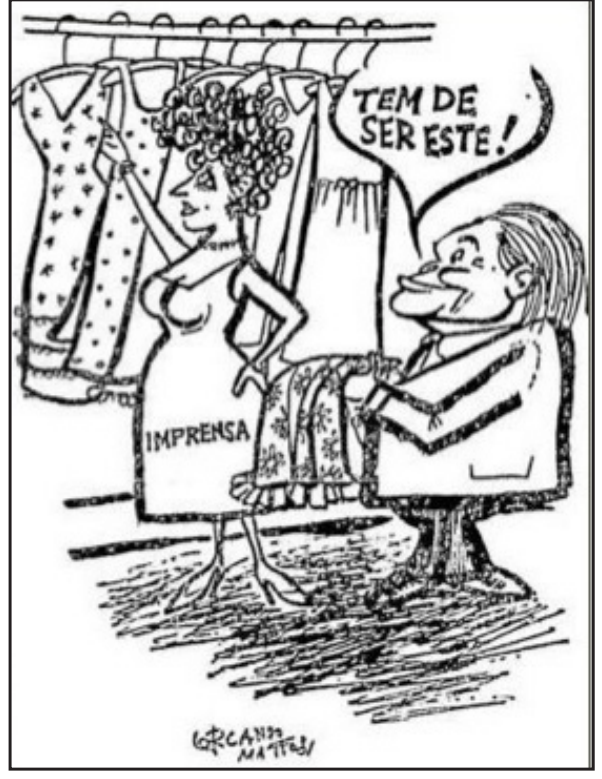

Figura 14: Orlando Mattos

Fonte: Folha de S.Paulo (22 jan. 1967).

O JB também diminuiu o apoio ao regime militar, sobretudo quando o autoritarismo se aguçou no fim de 1965. Assim como a FSP e OESP, o JB mostrou-se insatisfeito com o aparato legislativo criado no fim do mandato de Castelo Branco que, além da Lei de Imprensa, editou nova Lei de Segurança Nacional (mais dura que a anterior, em vigor desde 1953) e implantou nova Constituição, elaborada pelo Executivo e apreciada superficialmente pelo Congresso Nacional.

Entre os diários em foco, o jornal da família Marinho foi o único a não contar com caricaturas políticas no período. Por vezes ele republicou charges de jornais estrangeiros, como fez com desenho proveniente de Portugal alusivo ao Golpe de 1964. Produzida certamente por algum veículo da direita portuguesa, que $O$ Globo não identificou, a imagem faz alusão à dupla derrota de Goulart e dos comunistas (figura 15), e à vitória da "ordem e progresso" no Brasil. A ausência de charges políticas regulares era compensada por editoriais e reportagens bastante engajadas em favor da "revoluçáo", que o jornal gostava de adjetivar como "democrática". Mobilizado para ganhar a opinião pública em favor do novo regime, ${ }^{22}$ O Globo usou (e abusou) da estratégia de publicar matérias de tom alarmista que comprovariam os "crimes" atribuídos ao regime deposto, a saber, o envolvimento com o comunismo, notadamente o internacional, e os vínculos com a corrupção. Foram publicados manchetes e textos sensacionalistas sobre temas como a prisão de "espiôes" chineses e checos, a descoberta de planos terríveis dos comunistas ("incêndios, execuçôes em massa, depredaçôes”) e até a denúncia de um improvável cárcere secreto mantido no subsolo do prédio da UNE. ${ }^{23}$ Após a ênfase inicial no tom anticomunista, $O$ Globo assestou baterias também contra a corrupção, sobretudo a partir de editorial de título significativo: "Início de uma era de honestidade e decência". ${ }^{24}$

\footnotetext{
${ }^{22}$ Em uma de suas raras críticas a Castelo Branco, o jornal demandou maior cuidado do governo para trabalhar a opinião em favor do regime, sob o risco de perder a batalha para os propagandistas da oposição. A iniciativa de publicar matérias sensacionalistas sobre os derrotados de 1964 leva à conclusão de que o jornal resolveu fazer sua parte nesse combate.

${ }^{23}$ Ediçóes de 9/5, 16/5, 23/5, 25/5, 18/6 e 23/6/1964. Embora não tenha a intenção de analisar a fundo o tema da recepção/apropriação das representaçóes jornalísticas, vale a pena citar o resultado de uma pesquisa de opinião feita pelo Ibope em São Paulo, em maio de 1964. Ante a pergunta se achavam acertada ou errada a cassação de mandato dos deputados comunistas, $74 \%$ dos entrevistados responderam afirmativamente. Ao mesmo grupo foi perguntado se achava acertada ou errada a prisão de sindicalistas ligados aos comunistas, e a resposta de $72 \%$ dos entrevistados foi positiva. Os resultados da pesquisa estão no acervo do Arquivo Edgar Leuenroth (Unicamp).

${ }^{24}$ Publicado em 18/4/1964.
} 


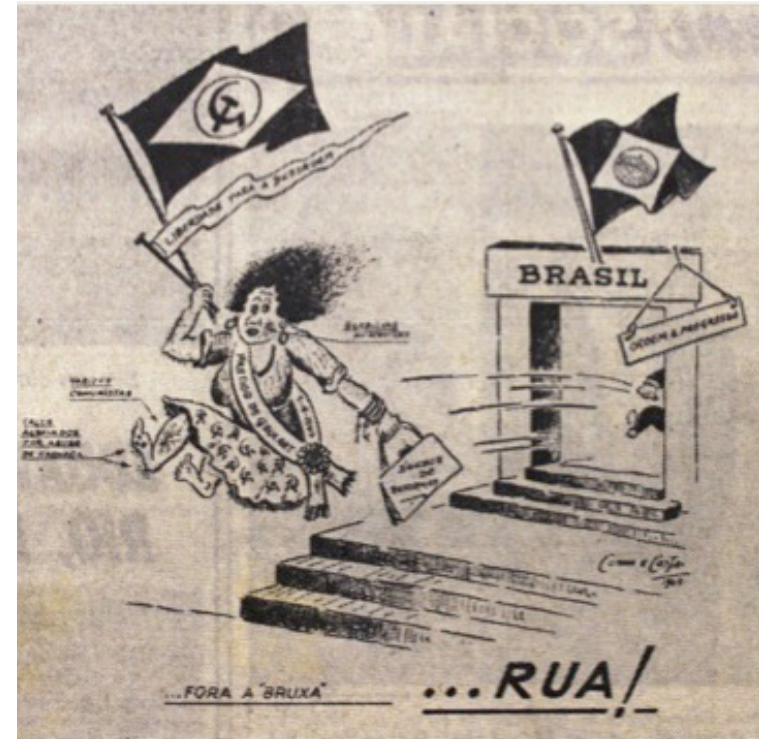

Figura 15: Anônimo e Costa

Fonte: O Globo (29 abr. 1964).

Não obstante apoiasse os expurgos, por vezes $O$ Globo pediu moderação ao governo, reclamando contra prisôes de artistas (por exemplo, da pintora Djanira e do apresentador de TV Carlos Imperial) que, em sua opinião, seriam equivocadas e contraproducentes. ${ }^{25}$ Comparando com FSP, OESP e JB, O Globo foi o mais fiel a Castelo Branco, mantendo os elogios ao marechal até mesmo no momento do AI-2, quando os outros se afastaram. O jornal de Roberto Marinho aprovou a institucionalidade autoritário-liberal legada por Castelo Branco ao país. Para $O$ Globo, o apoio ao novo Ato Institucional (o AI-2) era dever de patriotismo, pois sem ele a "revolução democrática" ficaria desprotegida em relação a seus inimigos. Na mesma linha, e sempre declarando amor à democracia, o diário fez a defesa do voto indireto para presidente, na sua visão uma prática mais ajustada à realidade nacional, pois o país não suportaria o choque das eleiçóes diretas. Nas entrelinhas, pode-se perceber a certeza (e o temor) de que os líderes do novo regime seriam incapazes de ganhar eleição nacional por sufrágio universal. ${ }^{26}$ Assim, O Globo mostrava-se concorde com um regime ditatorial morno, capaz de conciliar autoritarismo com alguns resquícios de instituiçóes liberais, o que de fato foi o cerne do regime militar brasileiro durante parte de sua vigência.

Os quatro diários analisados até aqui, pertencentes ao bloco dos apoiadores do novo regime, receberam com frieza a escolha de Costa e Silva para chefiar o segundo governo "revolucionário". Costa e Silva foi ironizado nas caricaturas de modo mais intenso que Castelo Branco, que era respeitado por sua tentativa de reestruturação do país segundo programa coerente. Costa e Silva foi visto como fraco continuador da obra de seu antecessor, posto que incapaz de apresentar projetos claros para o país. O ponto mais sensível das críticas, que viriam a se tornar mais fortes em 1968, dizia respeito à fragilidade do ministério, composto por figuras inexpressivas politicamente e com grande peso de militares. No entanto, esses diários buscaram se acomodar também com o novo presidente, principalmente quando ele começou a dizer-se disposto ao diálogo com a oposição e a atitudes moderadas, na primeira fase do seu mandato. Aqui cabe uma exceção para $O$ Globo, que criticou o governo pela

\footnotetext{
${ }^{25}$ Ediçóes de 23/5/1964 e 8/1/1969.

${ }^{26}$ Editoriais de 8/10 e 19/10/1965. Importante aduzir que $O$ Globo havia rompido violentamente com Carlos Lacerda, cuja imagem procurava demolir por essa época (1965 e 1966) ao publicar matérias acusando-o de corrupção. Portanto, para esse jornal não existia a opção eleitoral do líder civil mais identificado com o golpe de 1964, de modo que as eleiçóes diretas significavam derrota certa para $O$ Globo.
} 
tentativa de aproximação com a oposição, reclamando que deveria governar com a situação para não enfraquecer a Arena. ${ }^{27}$

No bloco minoritário, formado pelos diários $\mathrm{UH}$ e CM, temos os jornais que adotaram posiçôes críticas mais fortes desde o início do regime militar, inclusive permeáveis a argumentos da esquerda. No caso de Última Hora esse era o caminho natural, já que pertencia ao campo dos derrotados em 1964. Fundado em 1951 para apoiar Getúlio Vargas, o UH tornou-se janguista em seguida e apoiou posiçôes nacionalistas de esquerda no contexto pré-golpe. Por isso sofreu repressão imediata, com invasão e depredação de suas dependências nos primeiros dias de abril, cena denunciada em charge de Jaguar. O novo quadro trouxe dificuldades políticas e econômicas para Samuel Wainer, o proprietário, que em 1965 se desfez de empresas subsidiárias e manteve apenas a matriz carioca. ${ }^{28}$ No UH, depois do Golpe, continuaram a pontuar jornalistas e chargistas simpáticos às esquerdas, não obstante Wainer tivesse também preocupaçóes empresariais e comerciais. Na verdade, segundo suas memórias, Wainer desejava linha editorial mais amena, para evitar choques graves com os militares, mas seus auxiliares nem sempre o obedeceram. ${ }^{29}$ Inicialmente com Jaguar e, depois, com Henfil e Claudius, o discurso visual de UH denunciou, de modo mais agudo do que qualquer outro jornal, as prisóes (figura 16), o empastelamento da imprensa (figura 17) e as torturas nos quartéis (figura 18). Vale notar na última figura o ataque irônico ao discurso do governo sobre inexistência de torturas. O chargista menciona a visita de inspeção do general Ernesto Geisel a instalaçóes militares do Nordeste, que resultou em declaração negando as denúncias de tortura, e a imagem contradiz o discurso oficial.

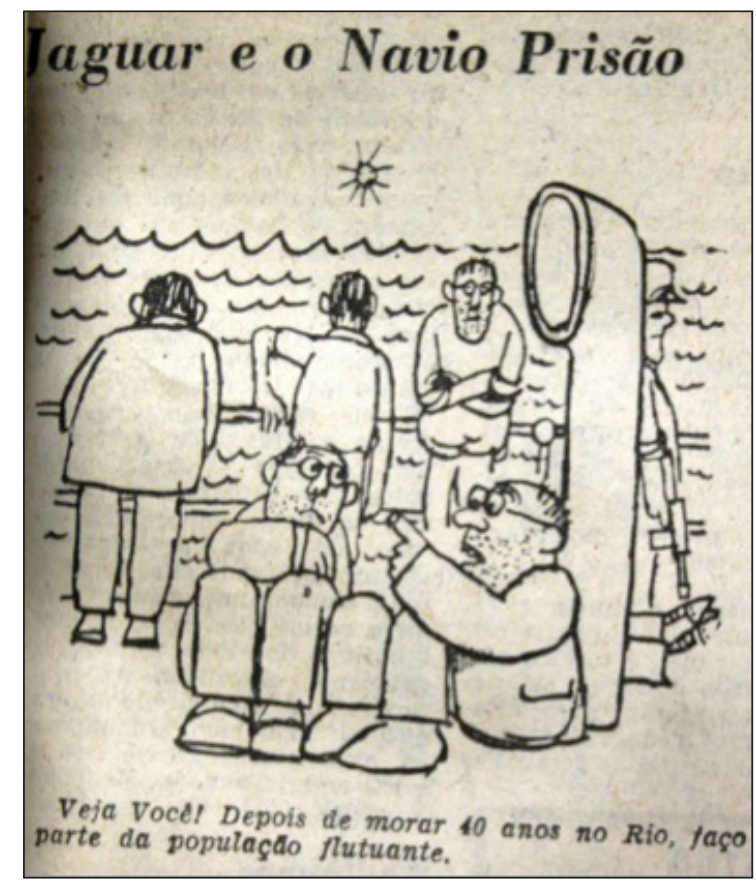

Figura 16: Jaguar

Fonte: Última Hora (13 abr. 1964).

\footnotetext{
${ }^{27}$ Editorial de 20/3/1967.

${ }^{28}$ LAURENZA, Ana Maria de Abreu. Batalhas em letra de forma: Chatô, Wainer e Lacerda. In: LUCA, Tania Regina de; MARTINS, Ana Luiza (Org.). História da imprensa no Brasil. São Paulo: Contexto, 2008. p. 203.

${ }^{29}$ WAINER, Samuel. Minha razão de viver. Rio de Janeiro: Record, 1980. Alguns editoriais de UH em 1964 mostraram, efetivamente, uma disposição para acomodação com o novo regime. Wainer viveu no exílio durante vários anos depois do Golpe, de modo que não era tão simples controlar a linha editorial de seu jornal, já que não podia acompanhar o dia a dia da redação.
} 


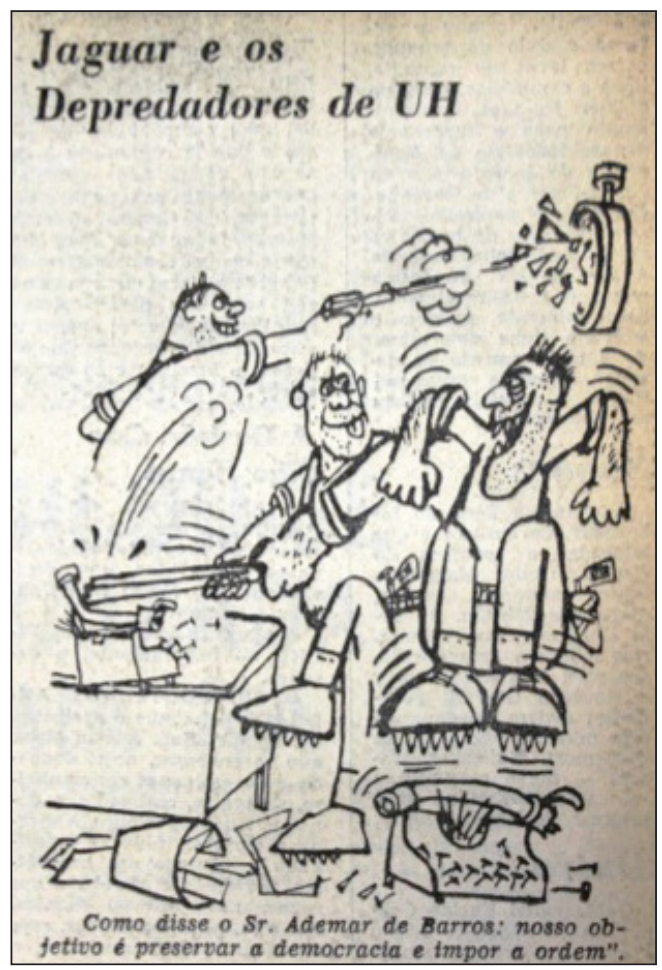

Figura 17: Jaguar

Fonte: Última Hora (4 abr. 1964).

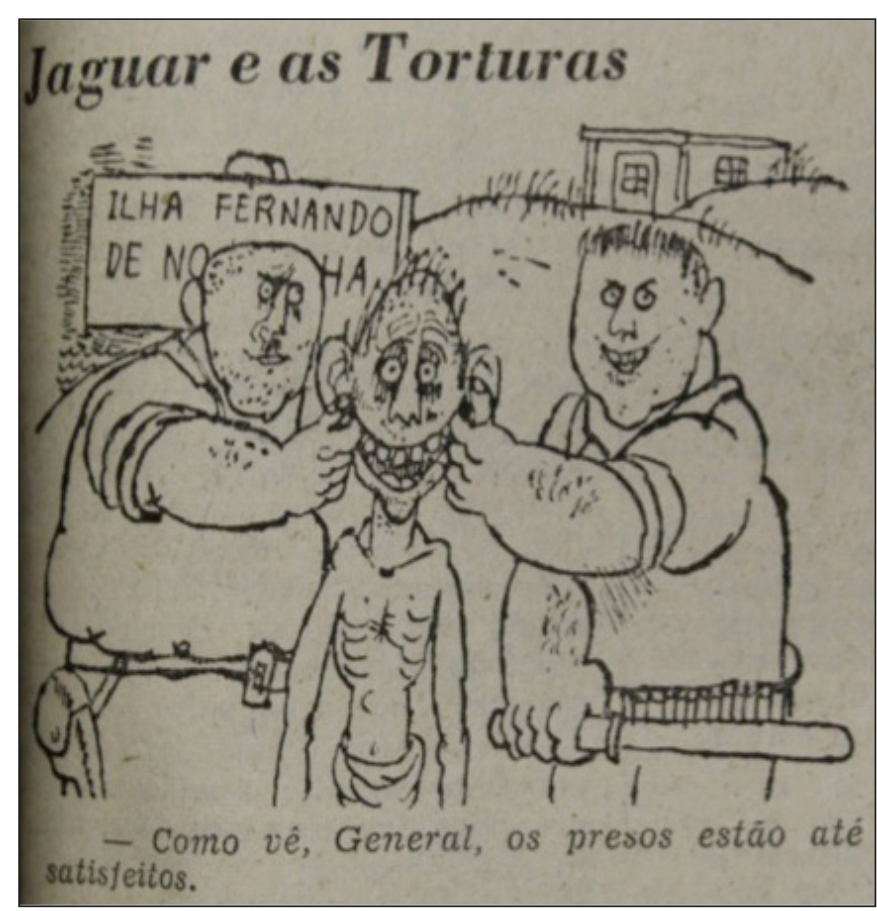

Figura 18: Jaguar

Fonte: Última Hora (19 set. 1964).

No caso do CM, tratava-se de jornal tradicional com longa história de embates contra vários governantes da República. Em 1963, o diário passou ao controle de Niomar Sodré, que procurou mantê-lo na linha de autonomia diante do Estado. O CM apoiou o Golpe e a derrubada de Goulart, embora fosse favorável a reformas sociais; porém, em poucos dias entrou em choque com o novo governo, discordando das medidas autoritárias. As atitudes ambíguas iniciais do jornal aparecem em algumas caricaturas de Augusto Bandeira, que oscilam entre a simpatia velada e a crítica sutil. Ressalto, em especial, a bela charge da "revolução" como figura feminina, que tenta forçar o Congresso e os partidos a cuidarem do "doente" Brasil (figura 19); e uma caricatura do expurgo de Castelo Branco, representado como zeloso "cabeleireiro" ou "faxineiro" ideológico da nação brasileira (figura 20).

Quando ficou claro que não haveria restabelecimento pleno da liberdade, UH e CM apresentaram as críticas mais ousadas e duras, fechando-se à possibilidade de um modus vivendi com o regime militar. O CM afastou-se decididamente da "redentora", que seus chargistas ironizaram em desenhos ferinos (figuras 21 e 22), ${ }^{30}$ e passou a contar com um time de artistas engajados contra a ditadura militar (Fortuna, Jota, Claudius, Mem de Sá, Rajão, Senna, Redí). Nos anos de 1967 e 1968, momento das grandes passeatas e confrontos sangrentos, as caricaturas e charges de UH e CM denunciaram corajosamente a violência policial (citando a PM e o Dops) e o terrorismo de direita, inclusive apontando as conexóes deste com agentes do Estado (figuras 23 a 25); ${ }^{31}$ encamparam alguns temas caros à esquerda, como a denúncia da influência imperialista norte-americana (figuras 26 e 27); ${ }^{32}$ e publicaram desenhos simpáticos às manifestaçôes de rua, com claro engajamento na luta contra o Estado militar,

\footnotetext{
${ }^{30}$ No caso da figura 22, note-se que o troglodita/gorila "cassa" com dois "s" em vez do "ç".

${ }^{31}$ Vale notar a suástica no braço do delegado e seu bigodinho ao estilo de Hitler (na figura 25) e a referência ao Esquadrão da Morte (EM) no camburão policial que aparece na figura 24.

${ }^{32} \mathrm{Na}$ figura 27, o baixinho de costas é Castelo Branco (por causa do pescoço atarracado) e também pela ironia com "Castle Filmes". A ironia é sutil, mas o conteúdo político é grave, a sugestão de que o presidente tinha relaçóes estreitas com os norte-americanos e seus dólares.
} 


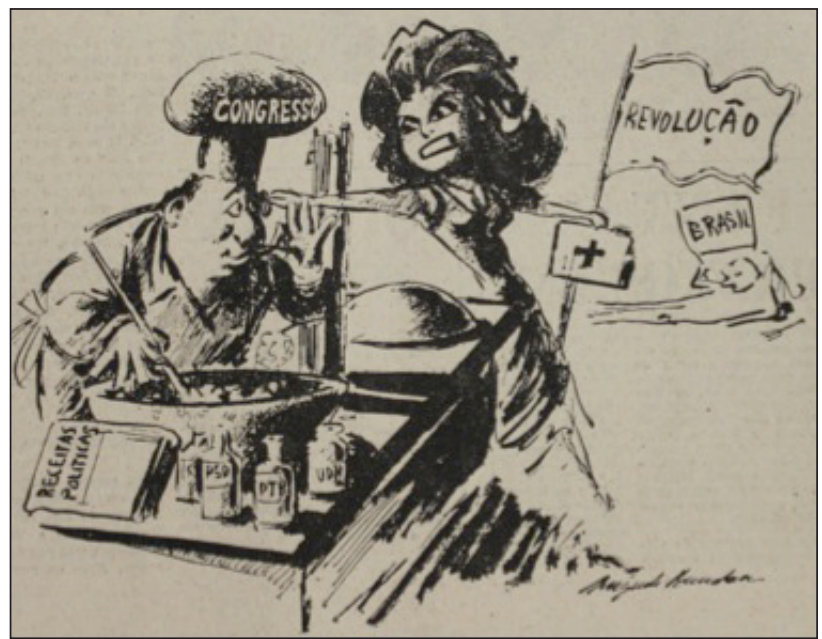

Figura 19: Augusto Bandeira

Fonte: Correio da Manhã (8 abr. 1964).

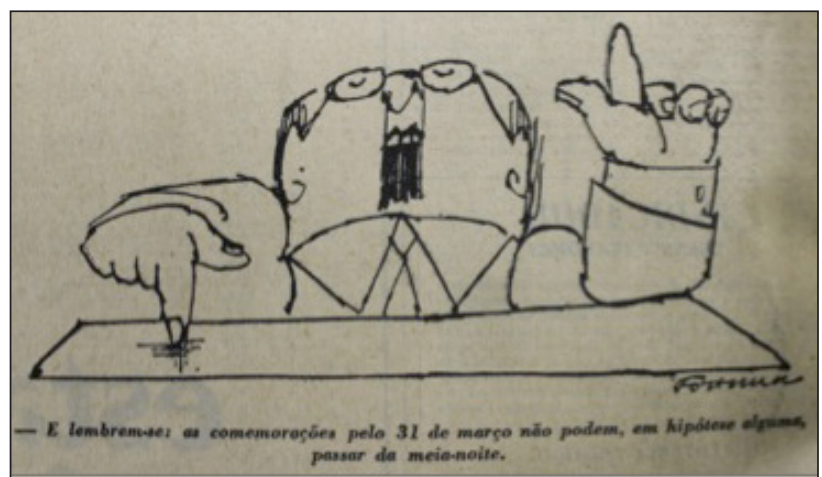

Figura 21: Fortuna

Fonte: Correio da Manhã (31 mar. 1966).

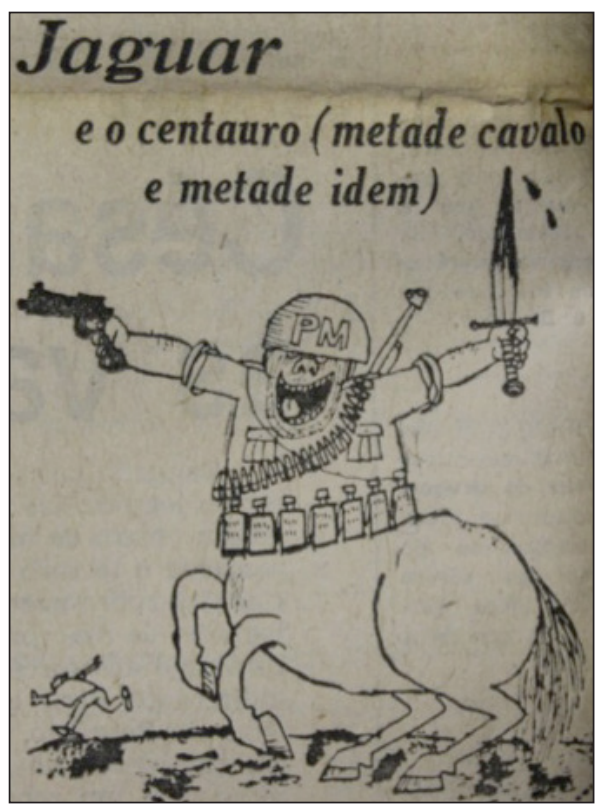

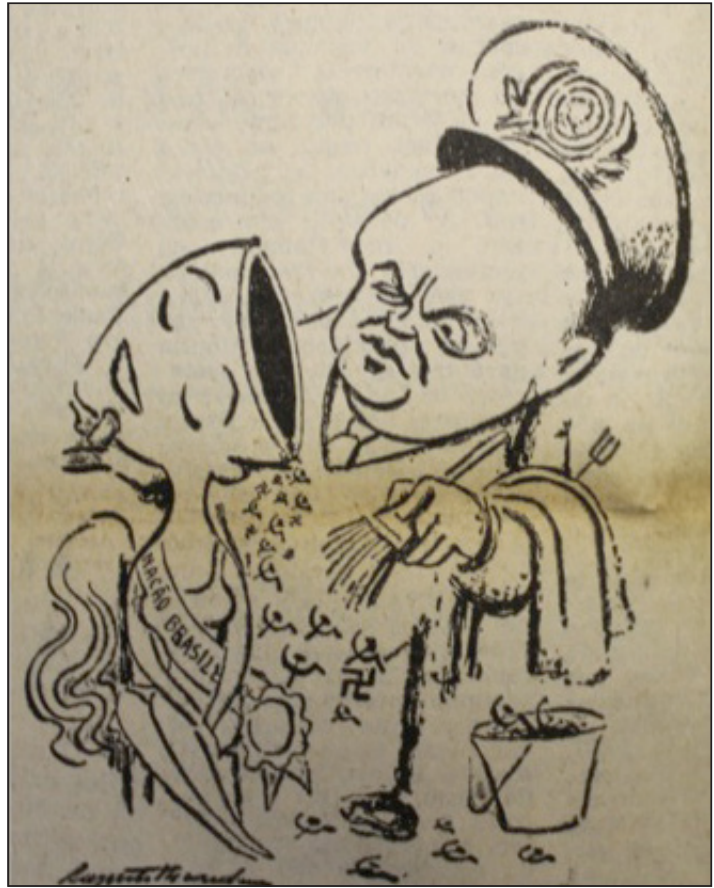

Figura 20: Augusto Bandeira

Fonte: Correio da Manhã (17 abr. 1964).

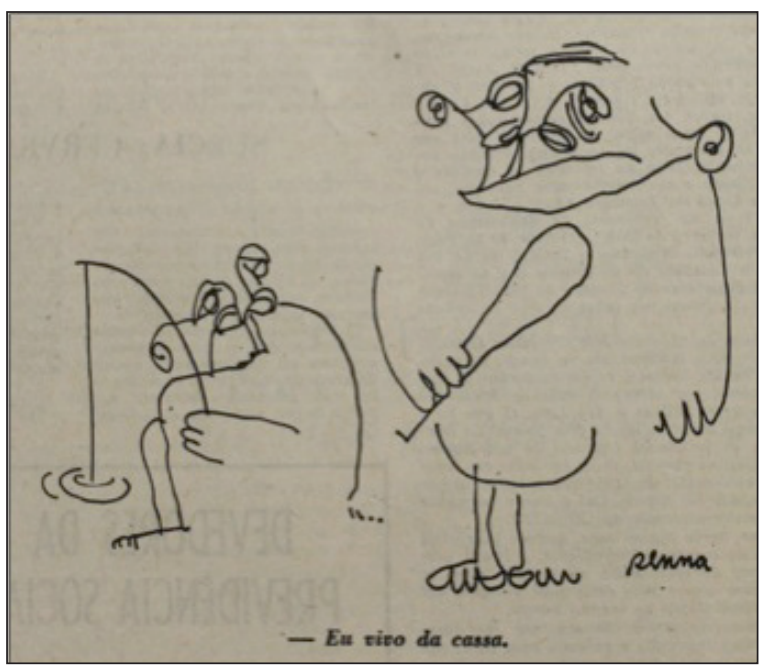

Figura 22: Senna

Fonte: Correio da Manhã (26 out. 1966).
Figura 23: Jaguar

Fonte: Última Hora (10 abr. 1968). 


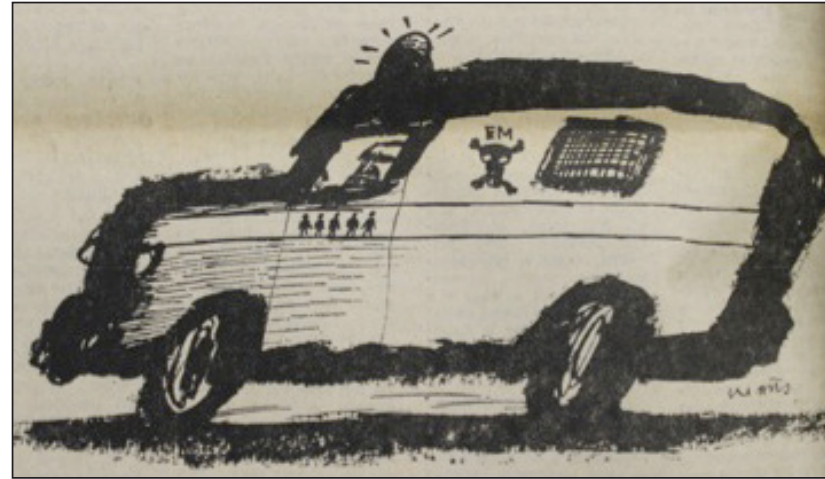

Figura 24: Claudius

Fonte: Correio da Manhã (24 out. 1968).

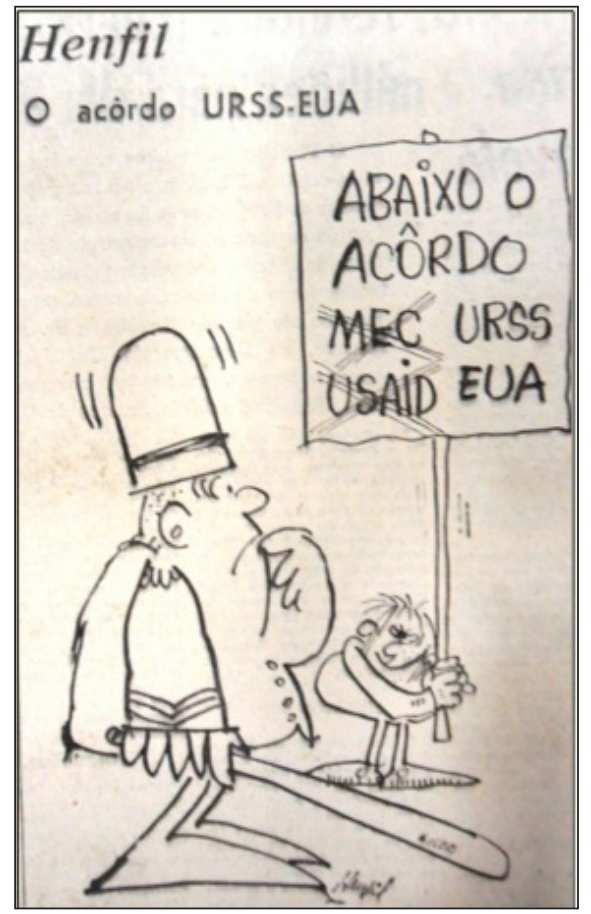

Figura 26: Henfil

Fonte: Última Hora (29 jun. 1967).

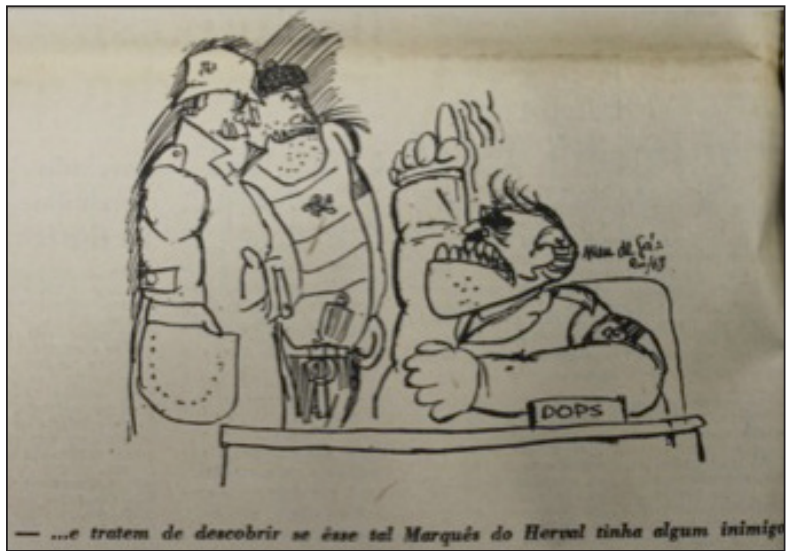

Figura 25: Mem de Sá

Fonte: Correio da Manhã (11 dez. 1968).

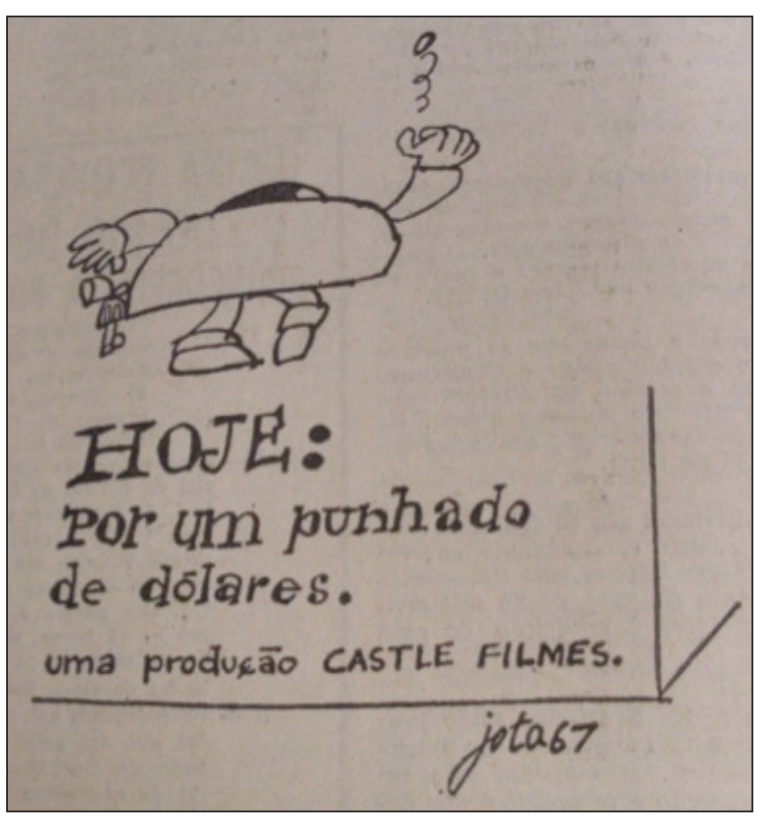

Figura 27: Jota

Fonte: Correio da Manhã (11 fev. 1967).

como na figura 28, em que a charge mostra um PM acorrentado enquanto padres, donas de casa e crianças desfilam tranquilamente em marcha de protesto, com cartazes aludindo à UNE e criticando a ditadura.

Voltando o foco para os jornais de linha liberal-conservadora, nos casos da FSP, JB e OESP, o agravamento da violência em 1968, bem como boatos sobre nova investida autoritária em gestação geraram críticas mais fortes ao regime. Não obstante, em comparação com o tom adotado em UH e CM, os ataques do JB, da FSP e do OESP foram mais leves, tendendo a concentrar a carga nos ministros do governo. Costa e Silva foi ironizado algumas vezes como chefe de governo inoperante, mas as figuras mais atacadas foram seus auxiliares. JB e FSP publicaram charges criticando as forças de repressão, tema praticamente ausente de sua pauta em 1964. A PM e o Dops surgem nos traços de Lan e Orlando Mattos, assim como denúncias contra o Esquadrão da morte (figuras 29 e 30). 


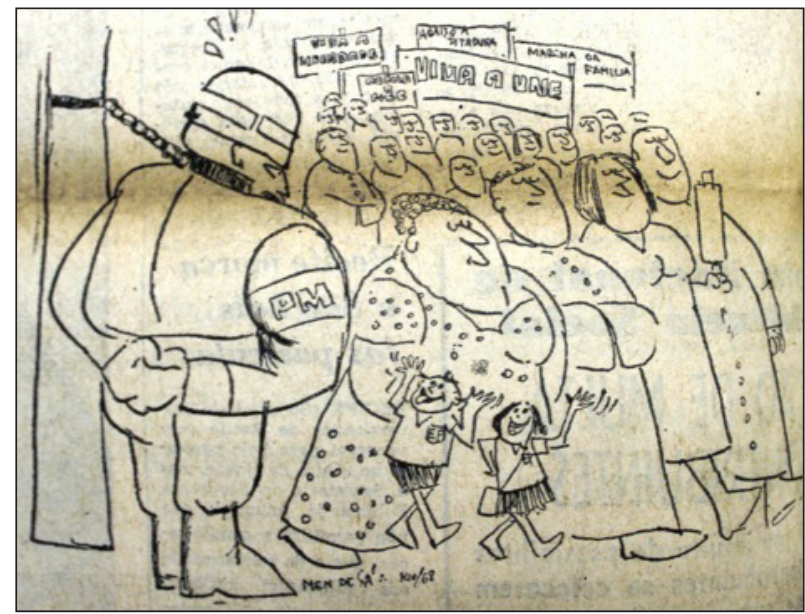

Figura 28: Mem de Sá

Fonte: Correio da Manhã (27 jun. 1968).

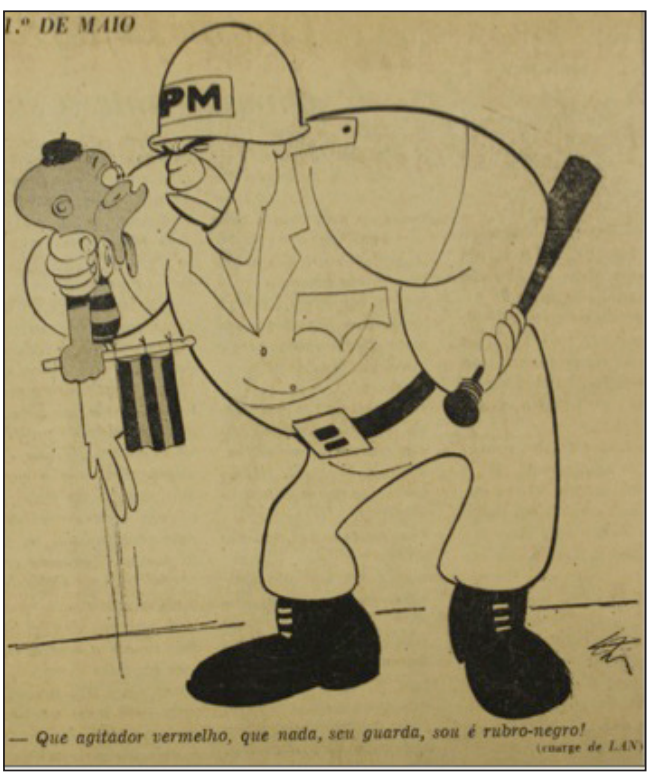

Figura 29: Lan

Fonte: Jornal do Brasil (1º maio 1968).

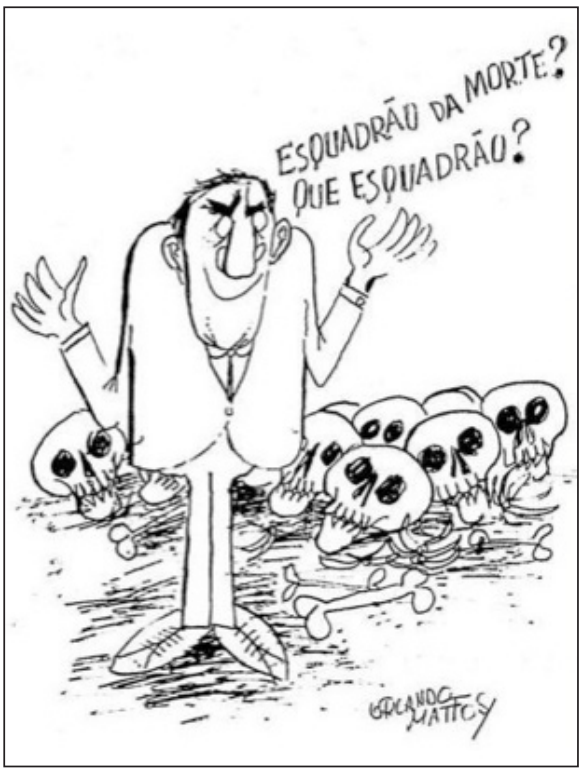

Figura 30: Orlando Mattos

Fonte: Folha de S.Paulo (5 dez. 1968).

No caso do Estadão, é mais significativa a diferença dos discursos emitidos em 1968 em comparação com 1964. O jornal mantinha contatos com a direita militar e o habitual discurso anticomunista; entretanto, abandonou o tom de apoio à repressão estatal, defendendo agora a democracia contra o autoritarismo. As charges de Hilde e Biganti, que em 1964 clamavam por mais dureza nos expurgos, em 1968 passaram a atacar a legislação autoritária por atentar contra os "ideais de março", e a criticar Costa e Silva (o Dr. C\&S) por violências contra a democracia (figuras 31 e 32).

Aqui cabe observação importante: JB, FSP e OESP também criticavam a radicalização dos segmentos da esquerda que antes do AI-5 já mostravam ter escolhido o caminho das armas. No entanto, nenhum dos três diários entendeu que novo ato autoritário era necessário para controlar a esquerda radical. Achavam que o Estado já dispunha de aparato suficiente para defender-se de qualquer desafio armado, e que a polarização entre a direita e a esquerda radical levaria o país ao abismo. Entendiam, também, que a crise de 1968 decorria, em parte, da incapacidade política e administrativa do governo Costa e Silva. JB e OESP defendiam uma reforma ministerial para mudar os rumos do governo e, juntamente com a FSP, esperavam que o impasse pela tentativa de punir o deputado Márcio Moreira Alves 


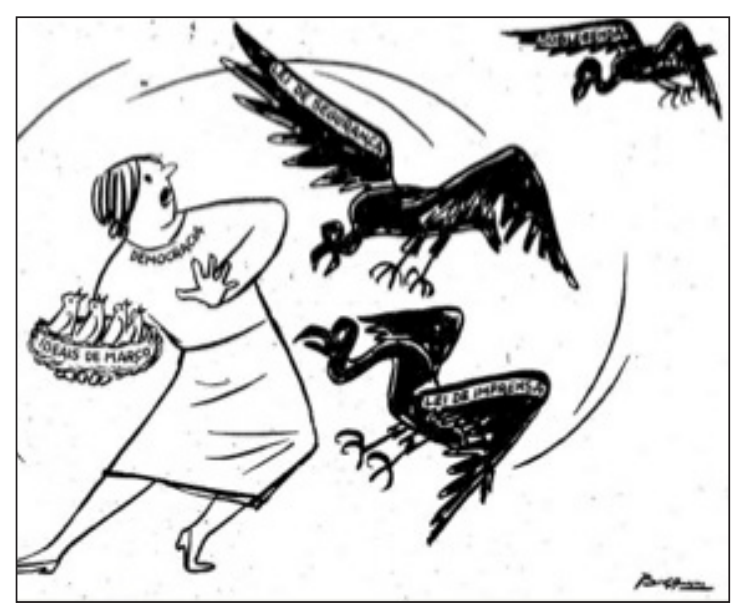

Figura 31: Biganti

Fonte: O Estado de S. Paulo (13 jun. 1968).

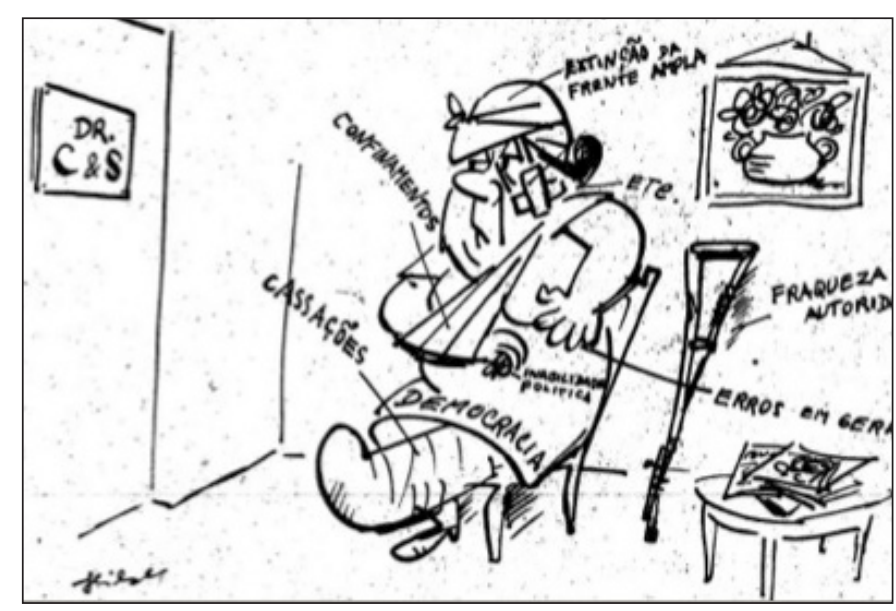

Figura 32: Hilde

Fonte: O Estado de S. Paulo (31 out. 1968).

fosse contornado. Na visão desses diários, a derrota do governo na votação do caso Moreira Alves não seria justificativa válida para novo surto autoritário. ${ }^{33} \mathrm{O}$ AI-5, decididamente, não estava em seus planos, inclusive porque seria previsível o aumento da censura à imprensa, o que efetivamente aconteceu.

Novamente, a posição de $O$ Globo foi diferente, com atitude mais simpática aos clamores autoritários da direita. ${ }^{34}$ Ele foi o único entre os seis diários a não manifestar discordância com o novo surto autoritário em preparação desde abril de 1968. O Globo criticou violentamente o que chamou "agitação" e "anarquia” nas ruas, e demandou ação do governo para impedir a desordem. Em editorial de 3 de abril de 1968, afirmou que a opiniáo pública exigia tranquilidade, cabendo ao governo erradicar a anarquia para preservar a democracia. No mesmo tom, voltou à carga em 8 de outubro de 1968, dizendo que a "revoluçáo de 31 de março" estava sendo desafiada pelos derrotados em 1964. Com seus textos alarmantes sobre os perigos circundando o regime militar e, supostamente, também a nação, $O$ Globo emitiu mensagens que estimulavam o leitor a aceitar a nova onda autoritária.

\section{O impacto do AI-5 sobre a imprensa}

A decretação do AI-5, no primeiro momento, significou a erradicação do debate político das páginas dos jornais. No dia 13 de dezembro de 1968, oficiais militares foram despachados para as principais redaçôes para realizar trabalho improvisado como censores, e aí permaneceram por algumas semanas. Por volta de abril/maio de 1969, os censores militares improvisados foram retirados e os jornais voltaram a tratar de política, cautelosamente. ${ }^{35}$

\footnotetext{
33 O deputado federal Márcio Moreira Alves, do MDB, fez um discurso agressivo contra o Exército na Câmara dos Deputados, por isso a tentativa do governo de puni-lo, o que demandava a suspensão das imunidades parlamentares com aprovação do Congresso. Os textos a mencionarem o caso, em geral, destacam que a parte mais polêmica do discurso foi quando sugeriu às mulheres boicotarem os jovens oficiais. No entanto, o ponto que realmente desagradou os militares foi a afirmação de que o Exército havia se transformado em "valhacouto de torturadores". Editorial de O Estado de S. Paulo, $5 / 11 / 1968$.

${ }^{34} \mathrm{O}$ cuidado em cultivar bom relacionamento com os governos autoritários, provavelmente, tinha relação com o período estrategicamente importante vivido pela empresa, que, então, construía seu império midiático.

${ }^{35}$ Logo a seguir entrariam em ação os censores profissionais da Divisão de Censura da Polícia Federal, embora o governo sempre negasse a existência de censura de natureza política. Formalmente, a legislação do regime militar garantia a liberdade de imprensa, salvo em situaçóes de atentado à moral e aos bons costumes e de propaganda de ideias visando à subversão da ordem. Na prática, a censura à imprensa foi realizada de maneira informal, ao arrepio do aparato legal.
} 
No caso do Estadão, a sua última manifestação política foi no dia 13 de dezembro, com o famoso editorial "Instituiçôes em frangalhos", que levou à apreensão da edição. No texto, Júlio de Mesquita Filho fez crítica demolidora ao governo Costa e Silva, responsabilizando-o pela crise e pela derrota do pedido para punir o deputado Márcio Moreira Alves. ${ }^{36}$ Segundo Mesquita Filho, o fracassado governo não tinha apoio da opiniáo pública e nem do Congresso, e o regime estaria por um fio, em vias de ser desmantelado. A intervenção no jornal coincidiu com a enfermidade de Mesquita Filho, que parou de escrever os editoriais e morreu em poucos meses.

Quanto ao Jornal do Brasil, a partir de maio de 1969 alguns editoriais apresentaram críticas leves ao governo, defendendo o retorno ao estado de direito. Em 21 de maio de 1969, editorial do JB afirmou que os brasileiros seriam democratas por convicção e apenas tolerariam (com resignação impaciente) as interrupçóes da liberdade, desejando sua plena recuperação. $\mathrm{O}$ tom não é de ataque pesado ao Estado, eles procuraram construir o texto com cuidado; mas criticaram o que consideravam excessivo cerceamento das liberdades individuais.

A Folha de S.Paulo foi mais cautelosa que o JB, e mais simpática ao novo presidente, Emílio G. Médici, que foi recebido com elogios e até uma charge amigável (figura 33). No entanto, o editorial (30/10/1969) que acompanha a charge falou do otimismo e das expectativas positivas geradas pelo discurso de posse de Médici, que prometera restabelecer a "plena normalidade democrática". Sutilmente, o editorial mencionou a importância do Poder Legislativo que, apesar das vicissitudes, na opinião do jornal "continua sendo o órgão mais representativo da opinião nacional".

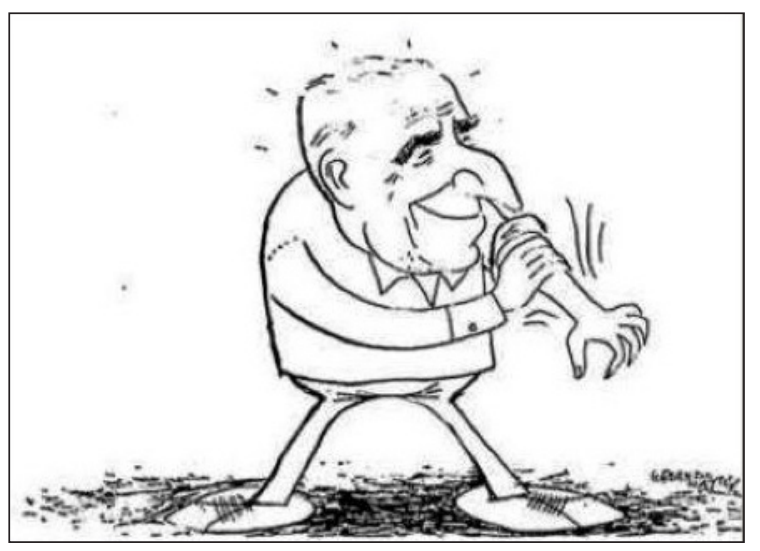

Figura 33: Orlando Mattos

Fonte: Folha de S.Paulo (30 out. 1969).

Embora desaprovassem o AI-5, o JB, a FSP e OESP não desejavam romper com o regime e estavam dispostos a acomodar-se com a nova situação, principalmente quando ficou claro que a economia entrara em ritmo vertiginoso de crescimento. Mesmo assim, o JB publicou críticas contra a violência estatal e a tortura, como no editorial de 3 de dezembro de 1969 que, a propósito de episódio de violência policial contra conhecido tenista, afirmou: "espancamentos e torturas não podem ser tolerados, em caso nenhum". O texto não falou da tortura contra adversários políticos, mas é evidente que isso estava nas entrelinhas.

Sem surpresa, dado o tom de seus editoriais de 1968, O Globo foi o diário mais simpático ao AI-5, o que tornava desnecessário enviar censores militares para sua redação. $\mathrm{O}$ jornal de Roberto Marinho evitou defesa aberta do novo AI e optou por linha cuidadosa, provavelmente para não agredir a opinião liberal. Mesmo evitando aderir inteiramente ao projeto ditatorial, as manifestaçóes do jornal em 1969

\footnotetext{
${ }^{36} \mathrm{O}$ Estadão defendia que o deputado merecia punição para desagravar a honra militar (editorial de 5/11/1968) e, com isso, pagava tributo a suas ligaçóes nos meios castrenses. Mas o jornal entendia que o caso não justificava o choque com o Congresso e uma crise de tamanhas proporçóes.
} 
mostraram manutenção do apoio ao regime. Editorial publicado em 4 de janeiro de 1969 fixou a posiçáo do jornal sobre o Ato. De acordo com o texto, $O$ Globo nem apoiava nem condenava o AI-5, que poderia ser instrumento positivo caso bem utilizado pelo governo; mas, advertindo Costa e Silva, dizia ter sido escolha arriscada, pois se tratava do último recurso do regime, que não teria mais margem para erro. Embora criticasse o que considerava alguns excessos repressivos, como a "ofensiva macartista" contra o Itamaraty, o jornal seguiu sustentando o regime, clamando pela uniáo da "família revolucionária" e convocando o governo a trabalhar pela naçáo, tirando proveito da compreensão do povo, que aceitaria "como transição, como mal necessário, uma fase de reajuste". ${ }^{37}$

No caso de UH e CM, o AI-5 significou o início do fim, que viria em pouco tempo. Os editores do CM tentaram enganar a censura, fazendo uma edição em 7 de janeiro de $1969^{38}$ com textos que denunciavam a situação opressiva, sem mostrar as provas da impressão para os oficiais de plantão. Vários jornalistas foram presos e também a dona do jornal, Niomar Sodré. Os proprietários de CM e UH acabaram por desanimar ante as dificuldades do novo quadro, em que um cerco financeiro organizado pela ditadura se combinou com o acirramento da concorrência no mercado jornalístico. Ambos foram vendidos e, com suas linhas editoriais desfiguradas, acabaram fechando as portas.

No que toca às caricaturas publicadas após 13 de dezembro de 1968 e ao longo de 1969, percebe-se o mesmo efeito devastador observado nos textos verbais. Desenhistas que antes criticavam em termos ácidos o regime militar passaram a tratar de temas anódinos e corriqueiros (o calor, o trânsito, os buracos no asfalto). Aliás, a situaçáo complicada dos chargistas foi retratada em desenhos que mencionavam as dificuldades do seu trabalho no novo contexto (figura 34). O único tema político passível de abordagem com menores riscos era o sistema partidário, pedra de toque no discurso governista que negava a existência da ditadura. No imediato pós-AI-5 o Congresso ficou suspenso por vários meses e essa espécie de "estado de coma" foi mencionada, com alusóes sutis à falta de perspectivas quanto ao futuro (a figura 35 retrata a renúncia do senador Daniel Krieger à presidência da Arena e também à vida pública, e a figura 36 usa metáfora infantil para mencionar, ironicamente, a incerteza sobre a continuidade do jogo partidário).

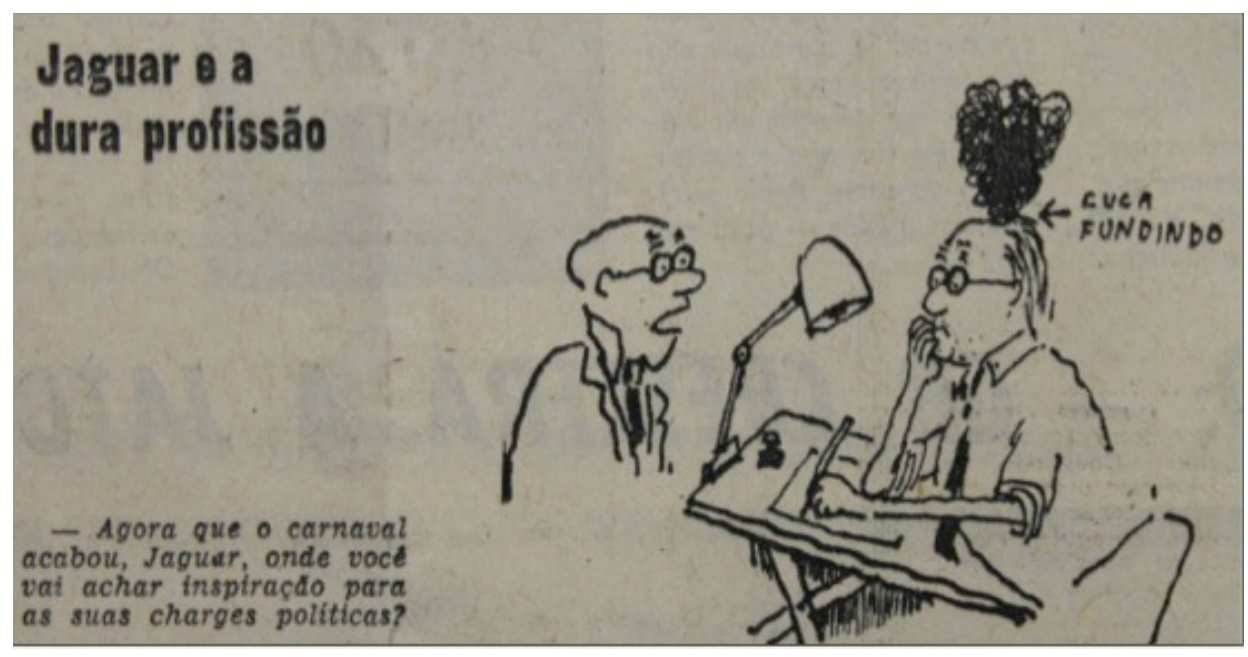

Figura 34: Jaguar

Fonte: Última Hora (25 fev. 1969).

\footnotetext{
${ }^{37}$ Editoriais de $11 / 2$ e 25/1/1969.

${ }^{38}$ ANDRADE, Jefferson de; SILVEIRA, Joel. Um jornal assassinado: a última batalha do Correio da Manhã. Rio de Janeiro: José Olympio, 1991. p. 42-44.
} 


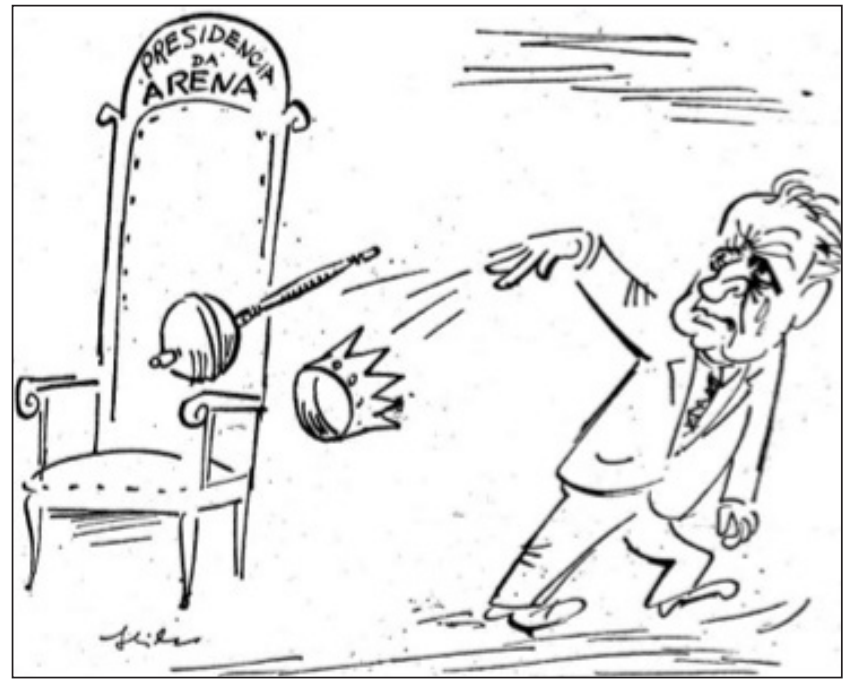

Figura 35: Hilde

Fonte: O Estado de S. Paulo (10 jan. 1969).

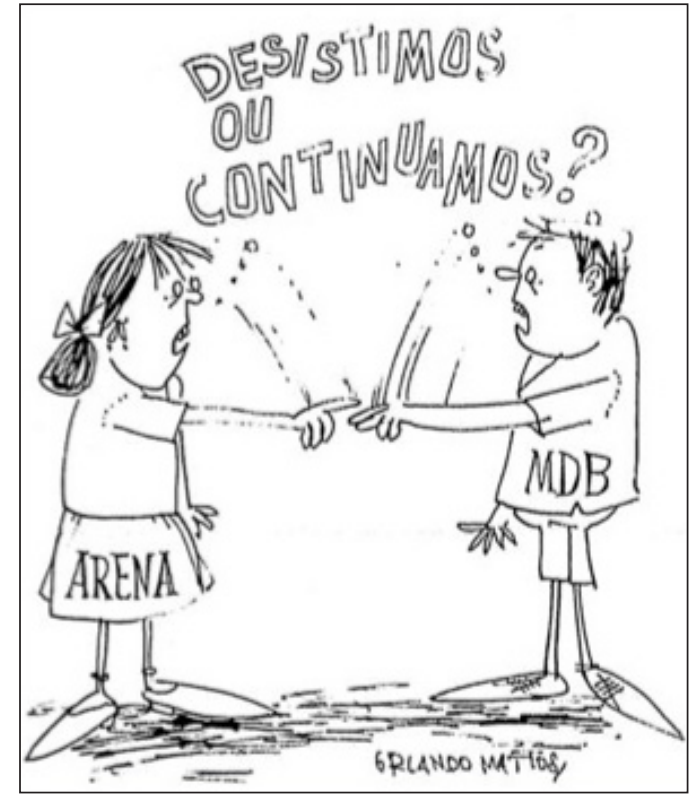

Figura 36: Orlando Mattos

Fonte: Folha de S.Paulo (27 abr. 1969).

Entretanto, mesmo na situação de censura e insegurança reinantes, alguns chargistas conseguiram publicar mensagens visuais sobre temas politicamente delicados, embutindo críticas nas entrelinhas (ou nos entretraços). Essas caricaturas, embora muito sutis, são particularmente significativas porque os editoriais políticos praticamente desapareceram em 1969. Alguns exemplos: utilizando o carnaval como metáfora, era possível sugerir a melancolia trazida pelo AI-5 (figura 37), assim como usar a baixa qualidade da programação televisiva para citar a presença da tortura, que era escamoteada pelo governo (figura 38); como era proibido noticiar as açôes da esquerda armada, por vezes foram feitas alusôes indiretas, como a charge sobre um homem armado querendo passagem para Havana (figura 39); e a figura de Tiradentes serviu para evocar os discursos e práticas antissubversivas do governo, questionando o nacionalismo oficial (figura 40), enquanto Tio Patinhas foi utilizado para mencionar, ironicamente, a presença do capitalismo norte-americano (figura 41). Enfim, os artistas do lápis encontraram meios sutis para contornar a censura, levando ao limite sua capacidade de criatividade a serviço do humor político. Nessa linha, por vezes, seu trabalho tornou-se um espaço de resistência ao autoritarismo, embora seja ingênuo supor uma recepção unívoca do público.

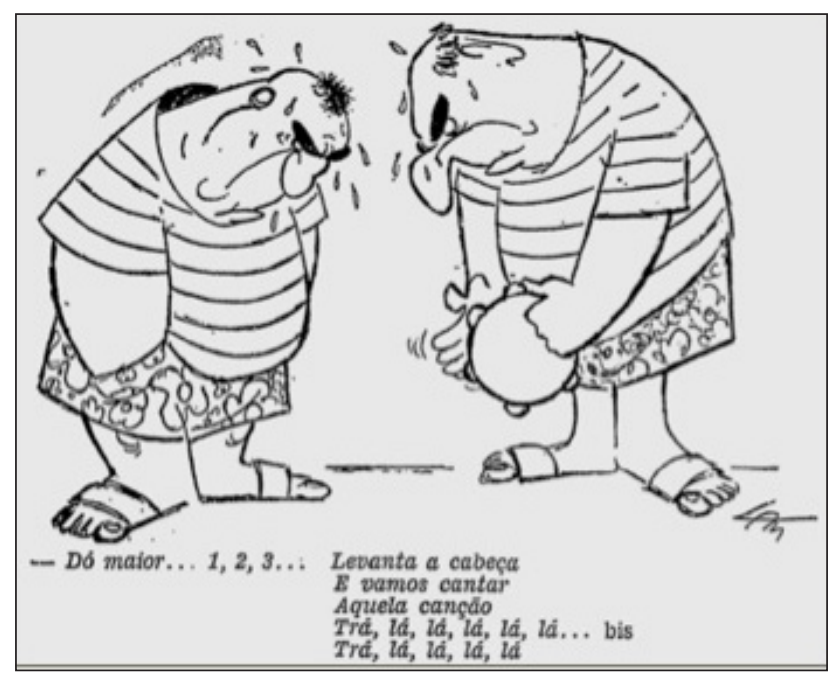

Figura 37: Lan

Fonte: Jornal do Brasil

(11 fev. 1969). 


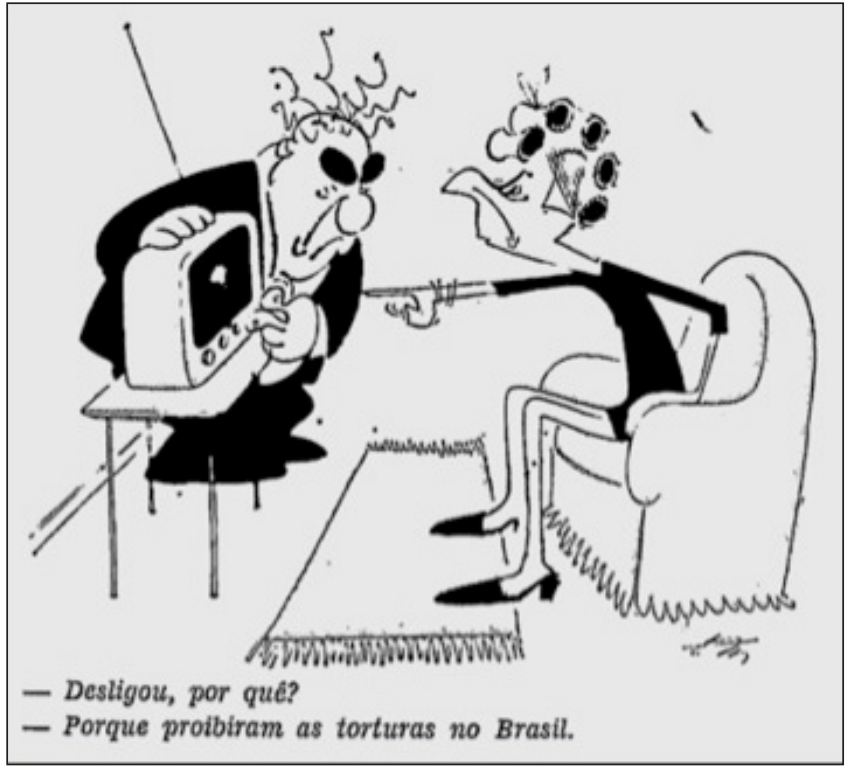

Figura 38: Lan

Fonte: Jornal do Brasil (11 dez. 1969).

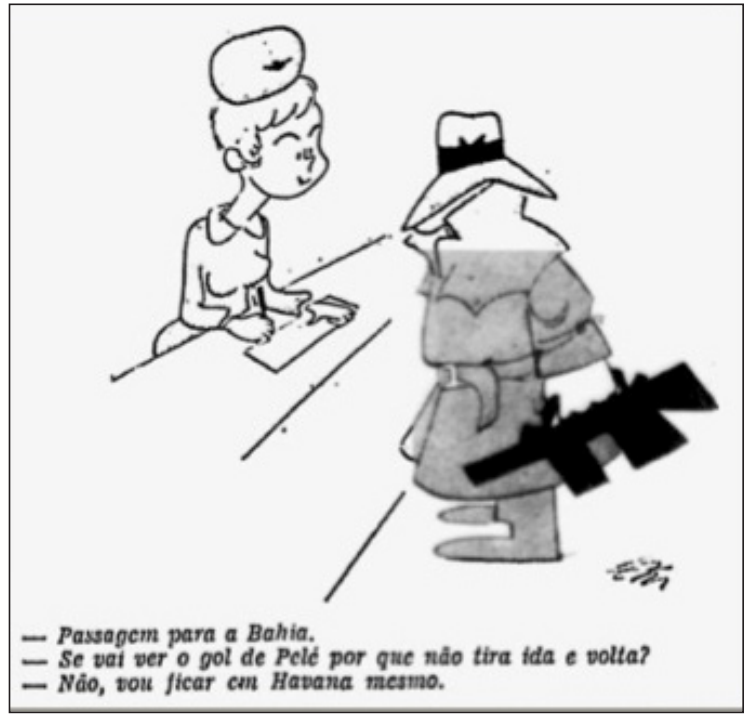

Figura 39: Lan

Fonte: Jornal do Brasil (15 nov. 1969).

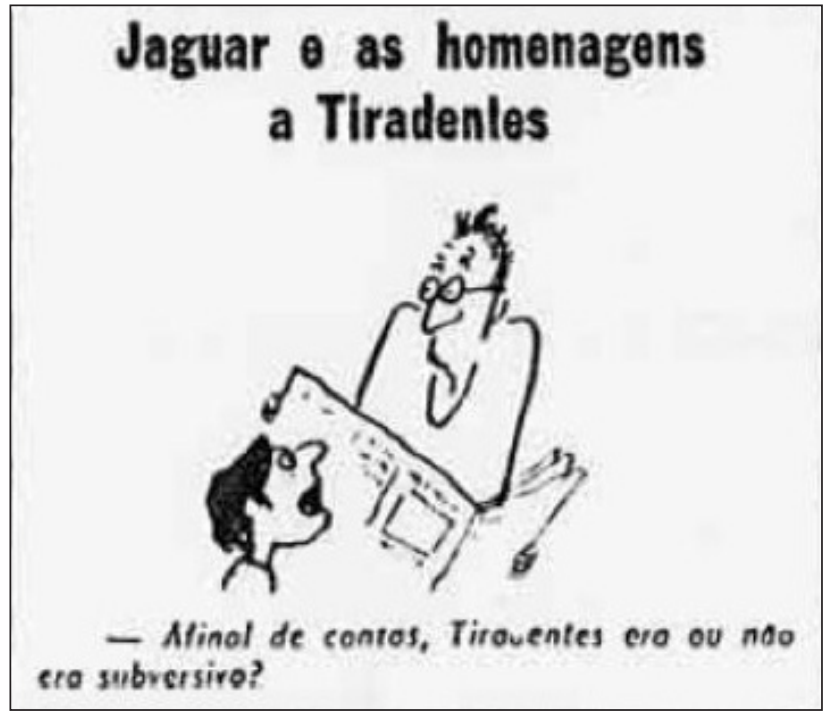

Figura 40: Jaguar

Fonte: Última Hora (21 abr. 1969).

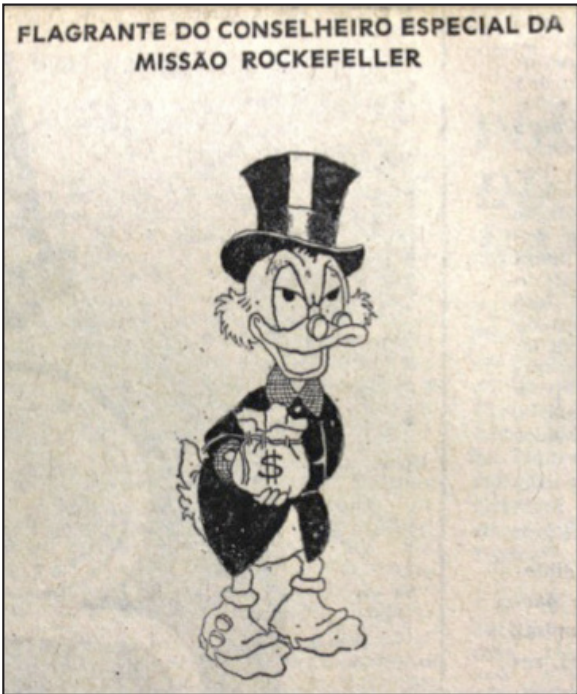

Figura 41: Anônimo

Fonte: Correio da Manhã (13 jun. 1969). 
Para finalizar, algumas consideraçôes sobre os discursos da imprensa e as tentativas de construir consenso em torno da ditadura. Mesmo se desprezássemos a influência dos diários de oposição para levar em conta apenas os jornais "revolucionários", a questão do consenso autoritário permaneceria complexa. Todos os jornais da grande imprensa professavam valores democráticos e liberais, que eram apresentados como fontes originadoras do regime de 1964, de modo que não se empolgaram (e por vezes se opuseram) com o surto ditatorial de dezembro de 1968. Quando os militares pretenderam implantar uma ditadura sem rebuços, livre de compromissos com as instituiçôes e valores liberais, eles encontraram fraco apoio na imprensa. Mesmo o dócil $O$ Globo temperava seu apoio ao AI-5 com declaraçôes de fé liberal, sugerindo que aceitava a situação autoritária como recurso passageiro.

Certamente, havia virtual consenso na grande imprensa quanto a políticas anticomunistas e antissubversivas, tanto em 1964 quanto em 1969. Porém, a maior parte dos diários achava que a repressão poderia ser compatível com respeito às instituiçóes e, em caso de supressão destas, que o período de exceção fosse breve. Exatamente pela falta de consenso em torno de programa autoritário claro, e por causa das representaçôes em torno dos chamados ideais liberais de 1964, todos os presidentes militares fizeram promessas de retorno à democracia plena, mesmo quando se ocupavam de golpeá-la. Por isso, também, a preocupação demonstrada pelos líderes dos sucessivos governos em negar que o regime fosse uma ditadura.

Os jornais da grande imprensa não se empolgaram com a obra política dos militares, principalmente quando a censura afetou sua liberdade, e evitaram adesáo aos valores autoritários. A falta de entusiasmo da imprensa em relação à ditadura e as críticas ocasionais tiveram o efeito de colocar sob tensão o experimento ditatorial, fortalecendo os argumentos da ala liberal do regime que pressionava por moderação. Porém, se é verdade que a imprensa não apoiou integralmente o projeto ditatorial, salvo nos primeiros meses após o Golpe, também não lhe fez oposição frontal, nem se dispôs a enfrentar o regime, exceto Última Hora e Correio da Manhã. Os grandes jornais, na maioria, se acomodaram à situação política, comportamento, aliás, comum na nossa cultura política.

Em linhas gerais, os grandes diários compactuaram com o regime e se adaptaram à situação autoritária, notadamente quando o quadro econômico da primeira metade dos anos 1970 gerou nova fonte de legitimidade para a ditadura. Com isso, a imprensa contribuiu indiretamente para a continuidade do regime militar, embora alguns de seus veículos prefiram, hoje, cultivar outro tipo de memória sobre o período. 